\title{
Anatomic glossary of mesopleural structures in Bethylidae (Hymenoptera: Chrysidoidea)
}

\author{
Chirlei Dias de Brito ${ }^{1,3}$; Geane de Oliveira Lanes ${ }^{2}$ \& Celso Oliveira Azevedo ${ }^{1,4}$ \\ 1 Universidade Federal do Espírito Santo (UFES), Departamento de Ciências Biológicas. Vitória, ES, Brasil. \\ 2 Secretaria de Educação do Estado do Espírito Santo (SEDU). Vitória, ES, Brasil. \\ ORCID: http://orcid.org/0000-0001-7679-5047.E-mail: geanelanes@gmail.com \\ 3 ORCID: http://orcid.org/0000-0002-1081-744X. E-mail: chirleidb@gmail.com \\ ${ }^{4}$ ORCID: http://orcid.org/0000-0002-2423-9388. E-mail: bethylidae@gmail.com
}

\begin{abstract}
The mesopleuron of Bethylidae has many structures that are used in taxonomic and phylogenetic studies. The lack of understanding of these structures has generated independent terminologies and a series of confusing terms, hampering effective scientific communication. A morphological study and literature review were made in order to solve these problems. Our study resulted in an anatomic glossary with 49 terms that presented a large number of synonyms and polysemies. The glossary standardizes the terms used in the Bethylidae mesopleuron and in other Hymenoptera groups, which will facilitate hypotheses of primary homology in comparative biology.
\end{abstract}

Keywords. Terminological polysemy; Terminological synonyms; Mesopleuron; Morphology.

\section{INTRODUCTION}

Most of the morphological studies of Hymenoptera have a generalized anatomical approach, in which all or large areas of the body are analyzed together (e.g., Gibson, 1985, 1993; Matsuda, 1970; Snodgrass, 1910; Vilhelmsen et al., 2010; Lanes et al., 2020). In addition, many of these studies are restricted to only a few groups within the order (e.g., Ibaliidae - Ronquist \& Nordlander, 1989; Platygastridae-Masner, 1979 and Mikó et al., 2007; Vespidae - Duncan, 1939 and Michener, 1944; Braconidae - Karlsson \& Ronquist, 2012 and Wharton, 2006; and Eupelmidae - Gibson, 1986).

Although these studies provided great contributions to the understanding of Hymenoptera and insect anatomy, anatomical studies restricted to more limited anatomical regions allow their characters to be discussed in more detail, and facilitates a more comprehensive comparative analysis. Examples are Shcherbakov $(1980,1981)$ and Gibson (1993), who contributed considerably to the understanding of the thoracic pleura of Hymenoptera, accomplishing a detailed study of the external and internal morphology, comparing structures, standardizing terms and discussing the variations in different taxa.

Despite the various morphological studies, many cladistic and taxonomic studies explore the anatomy of taxa in a restricted and particular way, creating new terms for the analyzed char- acters or using previous terms without further exploring the homology between the characters. Such factors contribute to a progressive increase in the number of polysemy and synonyms in the terminology. This is evident in groups within Hymenoptera, in which evolutionary events have caused the loss or fusion of various anatomical structures (e.g., mesopleural and mesopleurosternal sutures). To try to minimize these problems in Bethylidae, Kawada et al. (2015) carried out a study of the skeletomusculature of the metapostnotum to solve problems of delimiting the boundary between the metanotum and the propodeum. However, there are areas that still need a skeletomuscular study to understand their structures and propose homologies, such as the mesopleuron.

The Bethylidae mesopleuron presents a wide variety of structures of sulci, pits, foveae and impressions that are frequently used as taxonomic and cladistic characters (see: Evans, 1959; Alencar \& Azevedo, 2011 a; Azevedo et al., 2018b; Alencar \& Azevedo, 2013; Waichert \& Azevedo, 2009). Many of them are poorly understood, unexploited and there is no clarity about their homologies (e.g., mesepimeral sulcus in Ramos \& Azevedo (2012), Alencar \& Azevedo (2013), Barbosa et al. (2014); sub-anterior fovea in Alencar \& Azevedo (2011a); lower mesopleural fovea in Waichert \& Azevedo (2009)). Moreover, the variety of structures has generated many terms, resulting in high quantities of synonyms and polysemies, hampering the taxo- 
nomic and cladistic analysis (e.g., synonymous structures: mesepimeral suture by Ramos \& Azevedo (2012); mesopleural groove by Alencar \& Azevedo (2013) and postpectal carina by Lanes \& Azevedo (2008). Polysemous structures: sub-tegular groove by Waichert \& Azevedo (2009); subalar pit by Richards (1956) and Mikó et al. (2007)).

In an attempt to mitigate the overlapping of terms, many authors (e.g., Gibson, 1986; Karlsson \& Ronquist, 2012; Lanes et al., 2020; Mikó et al., 2007; Ronquist \& Nordlander, 1989) have comparatively analyzed the terminology applied to Hymenoptera characters (e.g., HAO, Antbase - Agosti \& Johnson (2005), Antkey - Sarnat \& Suarez (28/04/2021)). Nevertheless, the characters of the mesopleuron are still little understood by many authors, being necessary a more detailed organization of the concepts and terminology of these characters.

This study aims to propose a detailed glossary of the terms and concepts of mesopleural structures, as well as a list of synonyms, which will assist in future investigations of mesopleuron in Bethylidae and other groups of Hymenoptera, serving as a basis for comparison, understanding and character recognition as well as their use in phylogenies.

\section{MATERIAL AND METHODS}

\section{Sample}

Specimens of 33 genera of Bethylidae belonging to all five extant subfamilies were examined covering most of the diversity of the mesopleuron (Table 1). The homologies with other Hymenoptera families were made by comparisons with literature.

The examined material is from the following institutions: CASC: California Academy of Sciences, USA, San Francisco (R. Zuparko); CZMA: Coleção Zoológica do Maranhão, Brazil, Caxias (F. Limeira-de-Oliveira); ISAM: Iziko South African Museum, South Africa, Cape Town (S. van Noort); MNHN: Museum National d'Histoire Naturelle, France, Paris (Agnièle Touret-Alby, Bernardo Santos); NMKE: National Museum of Kenya, Kenya, Nairobi (R. Copeland); QMSB: Queensland Museum South Bank, Australia, Brisbane (Chris Burwell); QSBG: Queen Sirikit Botanic Garden, Thailand, Chiang Mai (W. Srisuka); UFES: Laboratory of Bethylidae at Universidade Federal do Espírito Santo, Brazil, Vitória (Celso O. Azevedo).

\section{Dissection techniques and images}

Critical-point-dried and air-dried specimens (Gibson, 1985; Vilhelmsen et al., 2010; Kawada et al., 2015) were used for morphological analysis, dissected with insect pins and razor blades. The specimen's parts were glued on a card with information on the sample's provenance and stored as vouchers.

The external and internal part of the mesopleuron was photographed with a Leica Z16 APO stereomicroscope coupled to a Leica DFC 2 video camera by Leica
Table 1. Genera examined.

\begin{tabular}{|c|c|}
\hline Subfamily & Genera \\
\hline \multirow[t]{4}{*}{ Bethylinae } & Goniozus Förster \\
\hline & Odontepyris Kieffer \\
\hline & Prosierola Kieffer \\
\hline & Sierola Cameron \\
\hline \multirow[t]{10}{*}{ Epyrinae } & Anisepyris Kieffer \\
\hline & Aspidepyris Evans \\
\hline & Bakeriella Kieffer \\
\hline & Chlorepyris Kieffer \\
\hline & Disepyris Kieffer \\
\hline & Epyris Westwood \\
\hline & Formosiepyris Terayama \\
\hline & Holepyris Kieffer \\
\hline & Laelius Ashmead \\
\hline & Trachepyris Kieffer \\
\hline \multirow[t]{6}{*}{ Mesitiinae } & Anaylax Móczár \\
\hline & Heterocoelia Dahlbom \\
\hline & Incertosulcos Móczár \\
\hline & Mesitius Spinola \\
\hline & Sulcomesitius Móczár \\
\hline & Zimankos Argaman \\
\hline \multirow[t]{8}{*}{ Pristocerinae } & Cleistepyris Kieffer \\
\hline & Dissomphalus Ashmead \\
\hline & Pristocera Klug \\
\hline & Pristepyris Kieffer \\
\hline & Propristocera Kieffer \\
\hline & Prosapenesia Kieffer \\
\hline & Protisobrachium Benoit \\
\hline & Pseudisobrachium Kieffer \\
\hline \multirow[t]{5}{*}{ Scleroderminae } & Cephalonomia Westwood \\
\hline & Sclerodermus Latreille \\
\hline & Prorops Waterston \\
\hline & Plastanoxus Kieffer \\
\hline & Proplastanoxus* Terayama \\
\hline
\end{tabular}

* The specimen information was taken from the literature.

Microsystems (Switzerland) following the lighting procedures of Kawada \& Buffington (2016). The image stacks were combined with Leica Application Suite V3.6.0 by Leica Microsystems (Switzerland) or Helicon Focus (HeliconSoft).

\section{Terminology}

The terms and descriptions of the morphological characters and muscles follow The Hymenoptera Anatomy Ontology project (Seltmann et al., 2012) available through The Hymenoptera Glossary (HAO http:// glossary.hymao.org) and Lanes et al. (2020). The homologisation of structures (primary homology) between Bethylidae and other Hymenoptera was made by comparing the shape, location and muscles associated with the structures. When it was not possible to establish homology through association with the musculature, we applied the criterion of the topographical sameness of structures (see Seltmann et al., 2012).

Lanes et al. (2020) and Seltmann et al. (2012) use the term homonymy when the same name is used for more than one structure. However, according to Martins (2015), 
the homonymy is related to cases in which two or more meanings are presented by words with the same spelling and/or sound, but have different semantic roots, while polysemy is characterized when a word with the same semantic root has two or more meanings. Furthermore, Alves (2000) explains that polysemy and homonymy may represent cases in which the same term is used to name different concepts, but polysemy deals with concepts from the same area or conceptual network, while homonymy from different conceptual areas or networks.

From that, we will adopt polysemy rather than homonymy when one name is applied to two or more structures and synonymy when the same structure has more than one different name applied to itself. We establish three criteria according to the order of the importance to define the preferential term: (1) was preferred the term that best represents the skeletal structure (shape and location in the body) according to Lanes et al. (2020), Ronquist \& Nordlander (1989) and HAO. (2) more widely used term in the scientific community; (3) oldest proposition of the term. The criteria adopted are informed in the description of the structure.

In polysemy cases or if the adopted terminology was not adequate (second criterion described in the previous paragraph), a new name was proposed. Some descriptions have been expanded because the previous definitions were insufficient to describe the characters. These definitions were structured following the genus differentia format, using the existing definition and from it we add the new part to cover the structural concept.

The positioning of characters in relation to the body follows the Biological Spatial Ontology - BSPO (Dahdul et al., 2014; BSPO) and the interpretation follows The Hymenoptera Anatomy Ontology (Yoder et al., 2010; Seltmann et al., 2012; HAO).

From the terminological glossary by Lanes et al. (2020) and the bibliography consulted, which presents information about structures of the mesopleuron in Hymenoptera (mainly morphological terms and concepts) and Bethylidae specifically (including taxonomic, morphological and cladistic terms applied to structures in mesopleuron), a new glossary for the mesopleural structures was made, in which the detailed description of the morphological characters and the commonly used synonyms were included. Valid terms and abbreviations are in bold and new terms are marked with one asterisk (*). In case of articles written in a non-English language, we translated the terms and kept the term in the original language in parentheses and marked with a double asterisk $\left(^{* *}\right)$. When the term represents only part of a structure, we include the term "in part".

\section{RESULTS}

\section{General description of the mesopleuron in Bethylidae}

Mesopleuron occupies a large part of the mesopectus (mesopleuron + mesosternum), being divided into lateral and ventral surfaces. Located dorsally in the lateral surface, the mesepimeral sulcus (epm2s) separates the posterior mesepimeral area (epm2pa) from the rest of the mesopleuron, which is composed of the mesepisternum and part of the mesepimeron. The posterior mesepimeral area is projected anteriorly, forming the mesepimeral lobe (mlo). The subalar area (saa) is located anterodorsally in the mesopleuron and is ventrally limited by the subalar impression (sai), within which are the anterior subalar pit (asup) and posterior subalar pit (psup). Ventral to the subalar impression may have the anterior mesopleural fovea (pl2af). Posteriorly to this fovea there are a mesopleural callus (pl2c) or an upper mesopleural fovea (pl2uf) or a posterior oblique sulcus of the mesopleuron (pl2pos). Centrally in the mesopleuron, the mesopleural pit (pl2p) is present, which can be internal to the upper mesopleural fovea or to the posterior oblique sulcus of the mesopleuron. Ventrally in the lateral surface, the lower mesopleural fovea (pl2 lf) is usually present and at the posterior extremity there is the mesopleural epicoxal lobe (p/2el), which may be limited by the mesopleural epicoxal sulcus (pl2es). In the ventral surface, subpleural signum (sps) and sternaulus (st) are usually present.

\section{Integumentary structures}

Acropleural apodeme (acra: Figs. 1A, 2D) = The apodeme located anterodorsally on the mesopleuron and correspondent to the site of origin of the third mesopleuro-mesonotal muscle (HAO_0000083). Although the acropleural apodeme is present in Bethylidae, we were not able to see the third mesopleuro-mesonotal muscle.

acropleural apodeme by Gibson (1986); Lanes et al. (2020); Mikó et al. (2007); Vilhelmsen et al. (2010).

Anterior mesopleural fovea (pl2af: Figs. 1B, C) = The small depression located near the anterior margin of the mesopleuron and ventral to the anterior end of the subalar impression (Lanes et al., 2020). Criterion 1.

anterior fovea by Alencar \& Azevedo (2013); Azevedo \& Alencar (2010a, b); Azevedo \& Barbosa (2010); Azevedo et al. (2005, 2018b); Barbosa \& Azevedo (2009, 2010, 2011b, 2014a, b, 2015); Barbosa et al. (2013); Lanes \& Azevedo (2008); Stein et al. (2011); Waichert \& Azevedo (2009).

anterior mesopleural fovea by Azevedo (2014); Barbosa \& Azevedo (2011a); Lanes et al. (2020).

Anterior subalar pit (asup: Fig. 1C) = The pit located anterodorsally on the mesopleuron that corresponds internally to the acropleural apodeme*. Criterion 1.

acropleural sulcus by Mikó et al. (2007). subalar pit by Richards (1956).

subtegular fovea by Azevedo \& Lanes (2009); Barbosa \& Azevedo (2009, 2011a); Barbosa et al. (2013); Lim et al. (2010). 


\section{Dorsal mesopleural inflection (pl2di: fig. 21B in Lanes} et al., 2020) = The inflection extending along the dorsal margin of the mesopleuron anterior to the posterior subalar pit, which articulates with the second axillary sclerite (HAO_0000257).

dorsal mesopleural inflection by Lanes et al. (2020); Mikó et al. (2007).
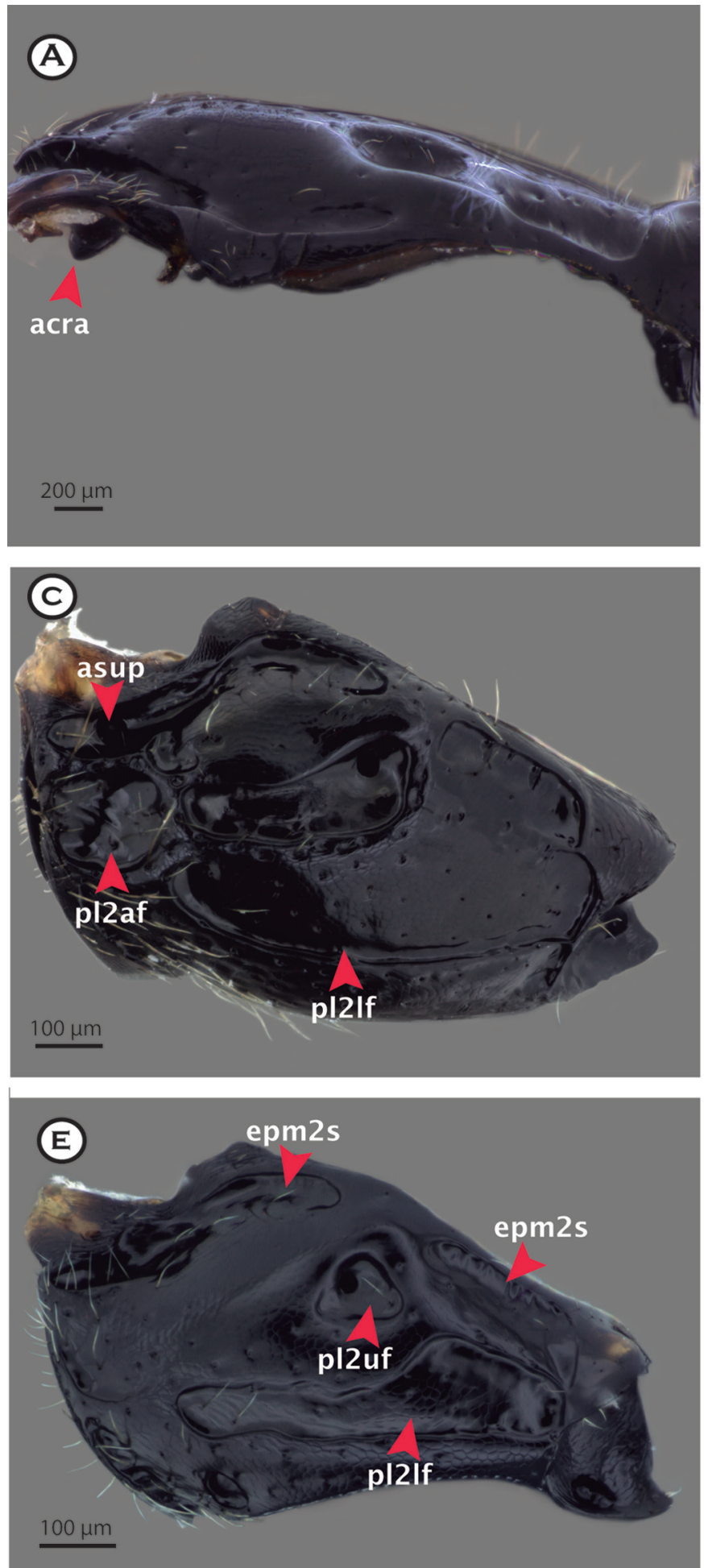

Lateral coxal articular process of the mesopleuron (Icapp2: http://api.hymao.org/public/figure/show zoom/12802 in HAO) = The articular process located ventrolaterally on the mesopleuron, where bears the lateral coxal condyle of the mesopleuron (HAO_0001464).

lateral coxal articular process of the mesopleuron by Boudinot (2015); Lanes et al. (2020).
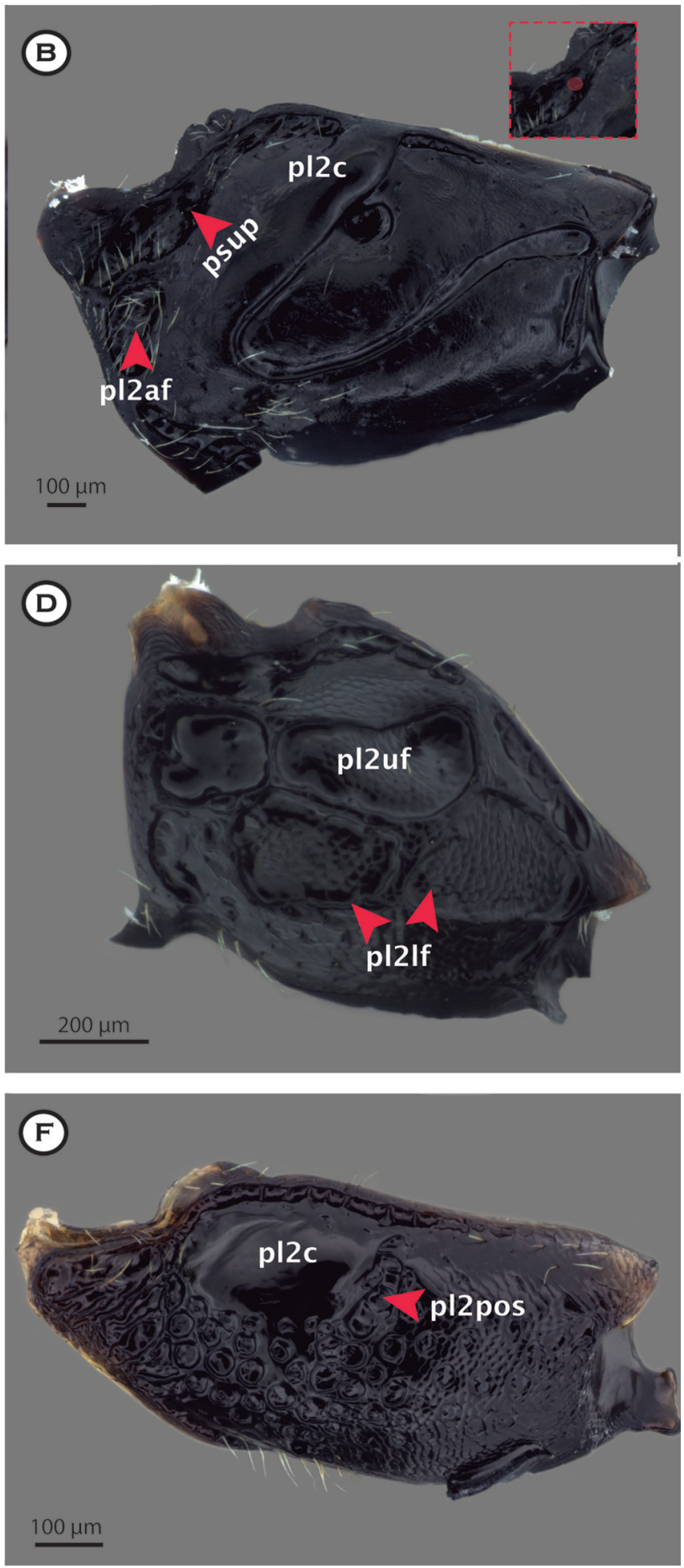

Figure 1. Mesopleuron. (A) Chlorepyris. (B) Epyris. (C) Chlorepyris. (D) Anisepyris. (E) Chlorepyris. (F) Pseudisobrachium. (A) dorsal view. (B-F) lateral view. Abbreviations: $\mathrm{acra}=$ acropleural apodeme; $\mathrm{pl} 2 \mathrm{af}=$ anterior mesopleural fovea; $\mathrm{psup}=$ posterior subalar pit; $\mathrm{pl} 2 \mathrm{c}=$ mesopleural callus; asup $=$ anterior mesopleural pit; pl2lf $=$

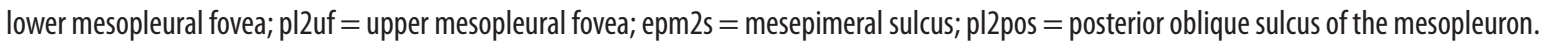


Lower mesopleural fovea (pl2lf: Figs. 1C, D, E) = Wide depression located ventrally to the mesopleural pit (Lanes et al., 2020). Criterion 2.

curved carina (in part) by Krombein (1992).

inferior margin of lower fovea by Alencar \& Azevedo (2011b); Stein et al. (2011).

lower fovea (or **fóvea inferior) by Alencar \& Azevedo (2013); Azevedo (1992, 1999a, c, 2011, 2014); Azevedo \& Alencar (2010a, b); Azevedo \& Barbosa (2010); Azevedo \& Mugrabi (2014); Azevedo et al. (2005); Barbosa \& Azevedo (2011a); Barbosa et al. (2013); Corrêa \& Azevedo (2002); Evans (1964, 1965, 1966a, 1967b, 1969c, 1978); Gobbi \& Azevedo (2006); Kawada \& Azevedo (2003); Krombein (1992); Moreira \& Azevedo (2003); Rosmann \& Azevedo (2005); Santos H.S. \& Azevedo (2000); Santos L.M. \& Azevedo (2008); Terayama (2006, 2008); Vargas \& Azevedo (2016a, b); Waichert \& Azevedo (2009).

lower margin (in part) by Azevedo (2014); Azevedo \& Alencar (2010a, b); Azevedo \& Mugrabi (2014); Santos L.M. \& Azevedo (2008).

lower mesopleural fovea by Azevedo et al. (2018b); Evans (1959, 1966b, 1970); Lanes et al. (2020); Lim \& Azevedo, 2014; Stein \& Azevedo (2007).

lower part of lower fovea (in part) by Evans, 1978. posterior fovea by Azevedo (1999a).

prepectal carina (in part) by Waichert \& Azevedo (2009). prepectal depression (in part) by Vargas \& Azevedo (2016b).

transepisternal line (in part) by Azevedo et al. (2018b); Lanes et al. (2020).

upper margin oflowerfóvea (in part) by Alencar \& Azevedo (2013); Azevedo (1994); Azevedo \& Alencar (2010b); Stein \& Azevedo (2007).

Medial coxal articular process of the mesopleuron (mcapp2: figs. 20B and 21A in Lanes et al., 2020) = The articular process located on the ventral margin of the mesopectus medially of the mesocoxal foramen, where bears the medial coxal condyle of the mesopectus (HAO/ Lanes et al., 2020). Criterion 1.

medial coxal articular process of the mesopectus by (HAO). medial coxal articular process of the mesopleuron by Lanes et al. (2020).

median mesocoxal articulation by Vilhelmsen et al. (2010). mesocoxal condyle by Karlsson \& Ronquist (2012).

Mesepimeral inflection (epm2i: Fig. 2B) = The inflection extending along the dorsal margin of the mesopectus (HAO_0000536). Criterion 1.

mesepimeral inflection by Lanes et al. (2020); Ronquist \& Nordlander (1989). posterior mesepimeral inflection by Mikó et al. (2007).

Mesepimeral lobe (mlo: Fig. 2F) $=$ The posterodorsal mesepimeral lobe covering the posterior thoracic spiracle (Karlsson \& Ronquist, 2012). Criterion 1. epimeral lobe by Richards (1956).

mesepimeral lobe by Karlsson \& Ronquist (2012).

Mesepimeral ridge (epm2r: Figs. 2A, B) = The ridge extending along the posterior margin of the mesopectus (HAO_0000537). Criterion 1.

mesepimeral ridge by Karlsson \& Ronquist (2012); Lanes et al. (2020); Mikó et al. (2007); Ronquist \& Nordlander (1989); Vilhelmsen et al. (2010).

posterior mesopleural apodeme by Duncan (1939).

Mesepimeral sulcus (epm2s: Figs. 1E, 2C) = The sulcus extending along the posterior margin of the mesopectus, which delimits the mesepimeral area and corresponds to the mesepimeral ridge (HAO_0000538). Criterion 1.

acropleural fovea (in part) by Barbosa \& Azevedo (2014a). acropleural sulcus (in part) by Barbosa \& Azevedo (2014a, b, 2015, 2016); Barbosa et al. (2017). episternal furrow by Azevedo \& Barbosa (2010); Azevedo \& Mugrabi (2014); Barbosa \& Azevedo (2010; 2011b, c, 2012); Barbosa et al. (2013); Lim \& Azevedo (2014); Stein et al. (2011).

episternal groove by Alencar \& Azevedo (2011a); Alencar et al. (2016); Azevedo (2008a, 2014); Azevedo et al. (2018a); Azevedo \& Alencar (2009); Barbosa \& Azevedo (2011a); Waichert \& Azevedo (2009).

mesepimeral sulcus by Azevedo et al. (2018b); Karlsson \& Ronquist (2012); Mikó et al. (2007); Vilhelmsen et al. (2010).

mesepimeral suture by Ramos \& Azevedo (2012). mesopleural groove by Alencar \& Azevedo (2013). mesopleural suture by Barbosa \& Azevedo (2014a, b, 2015,

2016); Barbosa et al. (2014, 2017); Lanes et al. (2020). postpectal carina by Lanes \& Azevedo (2008).

pleural sulcus by Richards (1956).

sub-alar fovea (in part) by Barbosa \& Azevedo (2009, 2010, 2011a); Lim et al. (2010).

subtegular fovea (in part) by Azevedo (2011); Azevedo \& Alencar (2010b); Azevedo \& Barbosa (2010); Azevedo \& Lanes (2009); Barbosa \& Azevedo (2011b, c, 2012). subtegular furrow (in part) by Ramos \& Azevedo (2012); subtegular groove (in part) by Alencar \& Azevedo (2009, 2011a, b); Alencar et al. (2016); Azevedo (2014); Azevedo \& Alencar (2009, 2010a); Azevedo \& Mugrabi (2014); Azevedo et al. (2018a, b); Lanes \& Azevedo (2007, 2008); Lim \& Azevedo (2014); Lim \& Lee (2013). sub-tegular groove (in part) by Waichert \& Azevedo (2009).

subtegular groove of mesopleuron (in part) by Lanes \& Azevedo (2008).

subtegular mesopleural fovea (in part) by Azevedo (2014).

Mesepimeron (epm2: http://api.hymao.org/public/ figure/show zoom/10827 in HAO) = The epimeron that is located on the mesopleuron (HAO_0000539). Criterion 1.

epimeron of mesopleuron by Snodgrass (1942). 
mesepimeron by Karlsson \& Ronquist (2012); Lanes et al. (2020); Michener (1944).

Mesepisternum (eps2: http://api.hymao.org/public/ figure/show zoom/10826 in HAO) = The episternum located on the mesopleuron (HAO_0000541). Criterion 1. mesepisternum by Lanes et al. (2020); Snodgrass (1910). mesothoracic episternum by Snodgrass (1942).

Mesocoxal foramen (cx2f: http://api.hymao.org/public/figure/show zoom/29356 in HAO) = The coxal foramen located on the mesopectus (HAO_0001785).
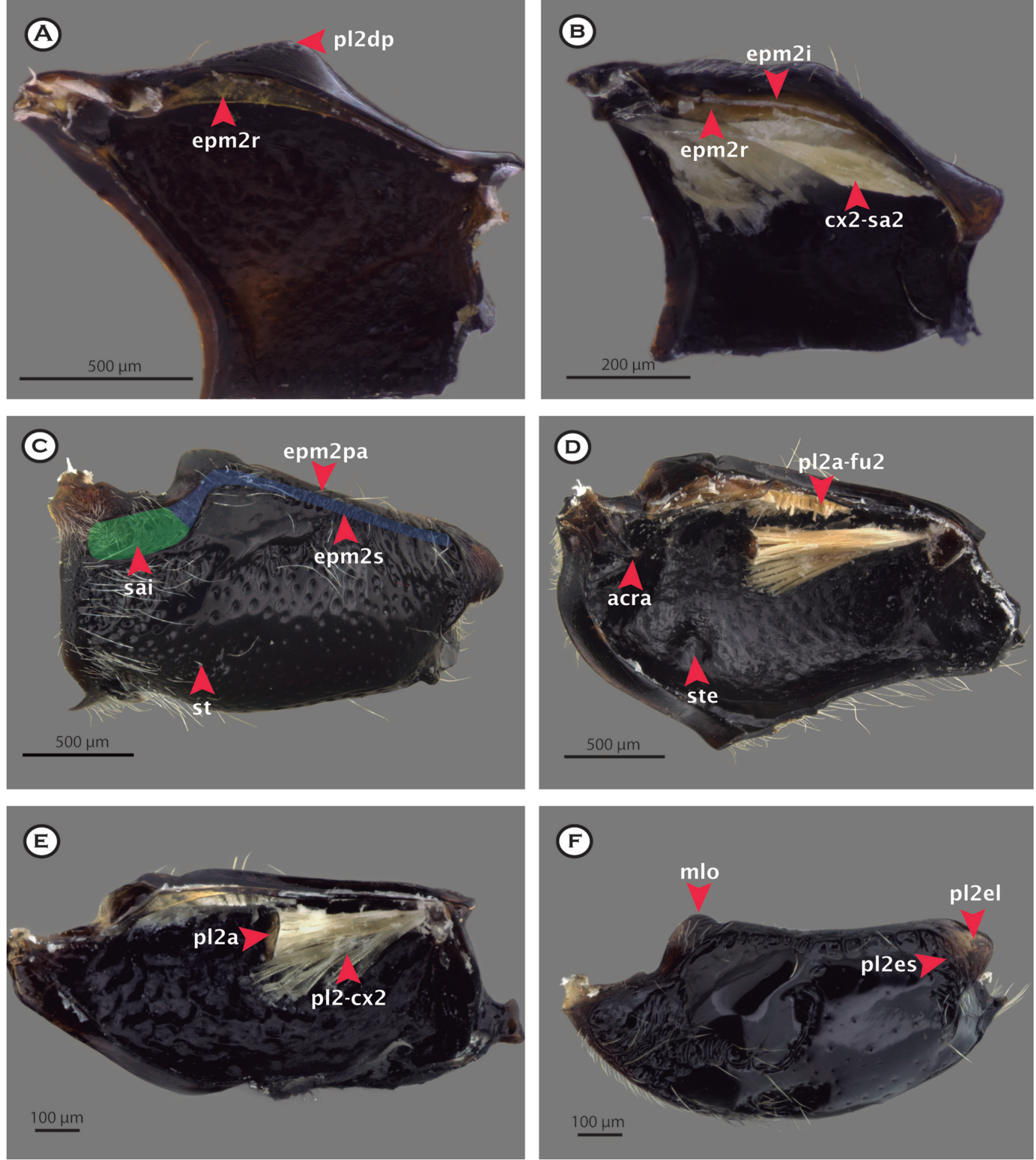

Figure 2. Mesopleuron. (A) Odontepyris. (B) Pristepyris. (C-D) Pristocera. (E) Pseudisobrachium. (F) Cleistepyris. (A, B, D, E) internal view. (C, F) lateral view. Abbreviations: epm $2 r$ = mesepimeral ridge; $\mathrm{pl} 2 \mathrm{dp}=$ mesopleural dentate process; epm2 $\mathrm{i}=$ mesepimeral inflection; $c \times 2$-sa2 = mesocoxo-mesosubalar muscle;

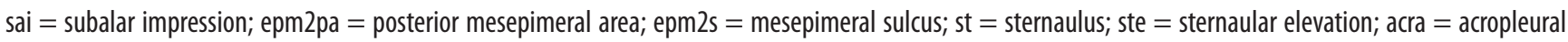
apodeme; $\mathrm{pl} 2 \mathrm{a}-\mathrm{fu} 2$ = anterior mesopleuro-mesofurcal muscle; $\mathrm{pl2a}=$ mesopleural apodeme; $\mathrm{pl2}-\mathrm{cx2}=$ mesopleuro-mesocoxal muscle; mlo = mesepimeral lobe; plzes = mesopleural epicoxal sulcus; plzel = mesopleural epicoxal lobe. 
mesocoxal foramen by Karlsson \& Ronquist (2012); Lanes et al. (2020); Vilhelmsen et al. (2010).

Mesopectus (pec2: http://api.hymao.org/public/figure/show zoom/28201 in HAO) = The sclerite which is U-shaped in cross section, and connected anteriorly with the pronotum and the propectus, dorsally with the basalare, the mesonotum, the second axillary sclerite and the subalare, posteriorly with the metapectus and bears the mesodiscrimenal lamella and the mesofurca (HAO_0000557).

mesopectus by Karlsson \& Ronquist (2012); Lanes et al. (2020); Vilhelmsen et al. (2010).

Mesopleural apodeme (pl2a: Figs. 2E, 3B) = The apodeme correspondent to the site of origin of the second mesopleuro-mesonotal and the mesopleuro-mesocoxal muscles (HAO_0001359). Criterion 1.

mesopleural apodeme by Karlsson \& Ronquist (2012);

Lanes et al. (2020); Vilhelmsen et al. (2010).

pleural apodeme by Mikó et al. (2007).

Mesopleural callus (pl2c: Figs. 1B, F) = The area corresponding to the site of origin of the second mesopleuro-mesonotal muscle and part of the mesofurco-mesopleural muscle. Externally, it is a bulging area located on the anterodorsal region of the mesopleuron, that is generally smoother than the rest*. Criterion 1.

acropleural area by Lanes et al. (2020).

callus by Azevedo (2004, 2007, 2008a); Azevedo et al.

(2018b); Corrêa \& Azevedo (2001, 2006;) Evans (1961,

1963a, b, 1964; 1966a, 1967a, c, 1969a, b, 1978);

Gobbi \& Azevedo (2014, 2016); Leal \& Azevedo

(2001); Ramos \& Azevedo (2009); Waichert \& Azevedo (2004).

mesopleural callus by Alencar \& Azevedo (2011a); Alencar et al. (2016); Azevedo \& Alencar (2009); Azevedo et al.

(2018a); Evans (1961, 1963b, 1973, 1978); Gobbi \&

Azevedo (2010); Zamprogno \& Azevedo (2014). mesopleural elevation by Alencar \& Azevedo (2009). mesopleural upper elevation by Alencar \& Azevedo (2013). supra-posterior callus by Alencar \& Azevedo (2013).

Mesopleural dentate process (pl2dp: Fig. 2A) = Projection located posterodorsally in mesopleuron (Lanes et al., 2020). Criterion 1.

blunt tooth by Krombein (1996).

dentate process by Alencar \& Azevedo (2011b); Azevedo et al. (2018b); Lim \& Lee (2013); Polaszek \& Krombein (1994).

dentate prominence $\left({ }^{* *}\right.$ dent aigüi) by Polaszek \& Krombein (1994); Kieffer \& Marshall (1904-1906). mesopleural dentate process by Lanes et al. (2020).

Mesopleural epicoxal lobe (pl2el: Fig. 2F) = Posterior region of the mesopleuron, anteriorly delimited by the mesopleural epicoxal sulcus. It usually overlaps the base of the mesocoxa*. Criterion 1.

mesopleural epicoxal lobe by Lanes et al. (2020); Ramos \& Azevedo (2012).

trochantial lobe by Richards (1956).

Mesopleural epicoxal ridge (pl2er) $=$ Internal ridge correspondent to the mesopleural epicoxal sulcus (Lanes et al., 2020).

mesopleural epicoxal ridge by Lanes et al. (2020).

Mesopleural epicoxal sulcus (pl2es: Fig. 2F) = The epicoxal sulcus located on the mesopleuron (HAO_0000560). Criterion 1.

mesopleural epicoxal sulcus by Lanes et al. (2020); Mikó et al. (2007).

postpectal carina by Waichert \& Azevedo (2009).

Mesopleural pit (pl2p: Fig. $\mathbf{3 C}$ ) = The pit correspondent to the mesopleural apodeme (HAO_0001358). Criterion 1.

antero-central pit by Azevedo (2007).

central pit by Alencar \& Azevedo (2009); Azevedo (1999b, 2005, 2006, 2008b, 2009a, b, 2014); Azevedo \& Alencar (2010a); Azevedo \& Barbosa (2010); Azevedo \& Lanes (2009); Barbosa \& Azevedo (2011b); Corrêa \& Azevedo (2002); Gobbi \& Azevedo (2006, 2014); Gupta et al. (2017); Kawada \& Azevedo (2003); Santos L.M. \& Azevedo (2003); Vargas \& Azevedo (2008, 2016a, b); Waichert \& Azevedo (2012).

episternal scrobe by Michener (1944); Richards (1956). mesopleural pit (or **die zentrale mesopleurale Grube) by Alencar \& Azevedo (2011b, 2013); Alencar et al. (2016); Argaman (2003); Azevedo \& Mugrabi (2014); Azevedo et al. (2018b, c); Evans (1969c); Lanes \& Azevedo (2008); Lanes et al. (2020); Ramos \& Azevedo (2012); Ramos et al. (2014); Sorg (1988); Stein et al. (2011); Vilhelmsen et al. (2010); Waichert \& Azevedo (2009, 2012).

mesopleural scrobe by Karlsson \& Ronquist (2012). pleural aphophysis by Snodgrass (1942). pleural pit by Masner, 1979; Mikó et al. (2007). small pit by (or **fossette) by Benoit $(1952,1957)$; Kieffer $(1904,1905,1906,1908,1910,1911)$.

Mesopleural wing process (pl2wp: figs. 28, 50 in Gibson, 1986) $=$ Projection of the anterodorsal corner of the mesopleuron (Lanes et al., 2020). Criterion 1.

mesopleural wing process by Gibson (1986).

pleural wing process by Duncan (1939); Gibson (1993); Snodgrass $(1909,1935)$.

Posterior mesepimeral area (epm2pa: Fig. $2 \mathrm{C}$ ) = The area extending along the posterior margin of the mesopleuron, which is delimited anteriorly by the mesepimeral sulcus (HAO_0000751). Criterion 1. 
mesepimeral flange by Karlsson \& Ronquist (2012).

posterior mesepimeral area by Lanes et al. (2020); Mikó et al. (2007).

Posterior oblique ridge of the mesopleuron ( $p / 2$ por:

Fig. 3B) = The internal oblique ridge corresponding to
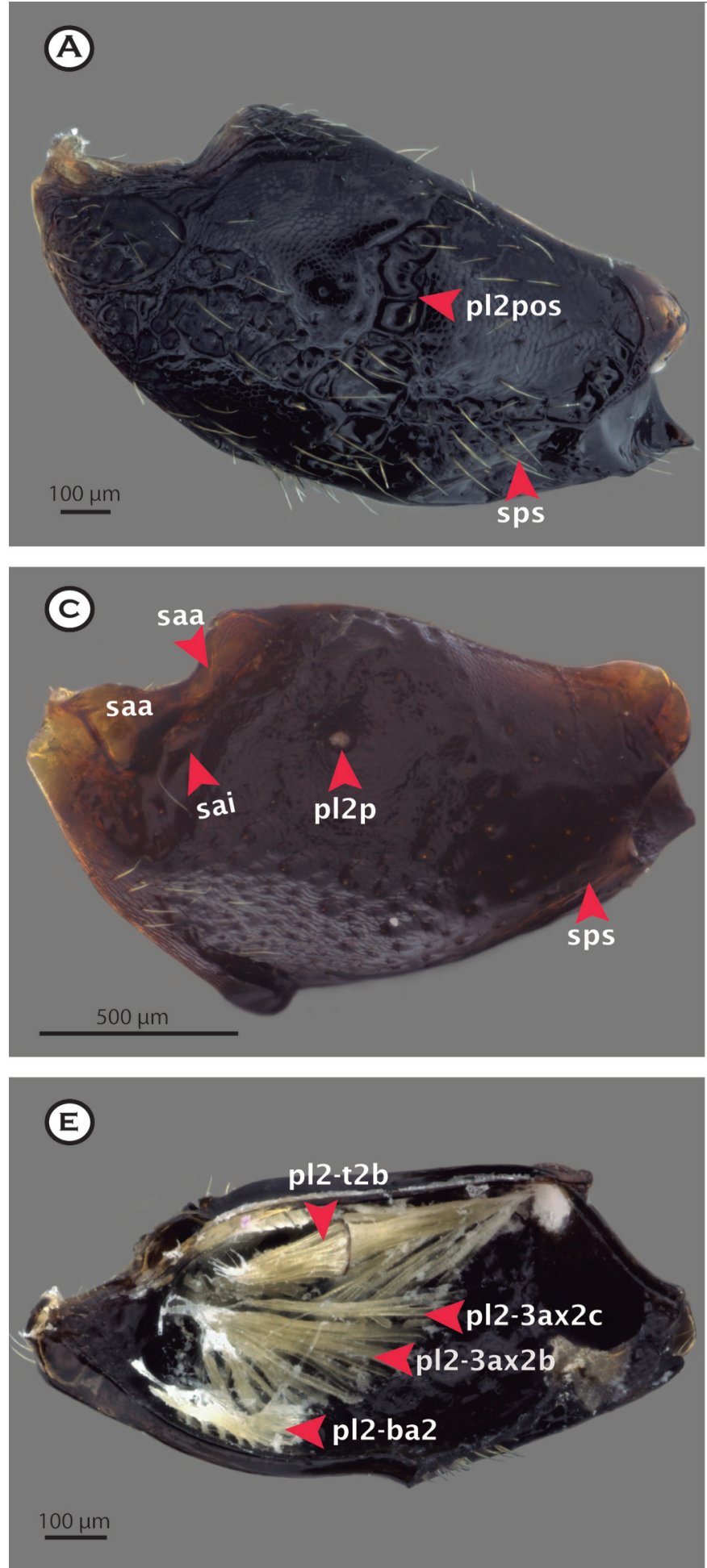

the posterior oblique sulcus of the mesopleuron (Lanes et al., 2020). Criterion 1.

oblique mesopleural ridge by Vilhelmsen et al. (2010). posterior oblique ridge of the mesopleuron by Lanes et al. (2020).
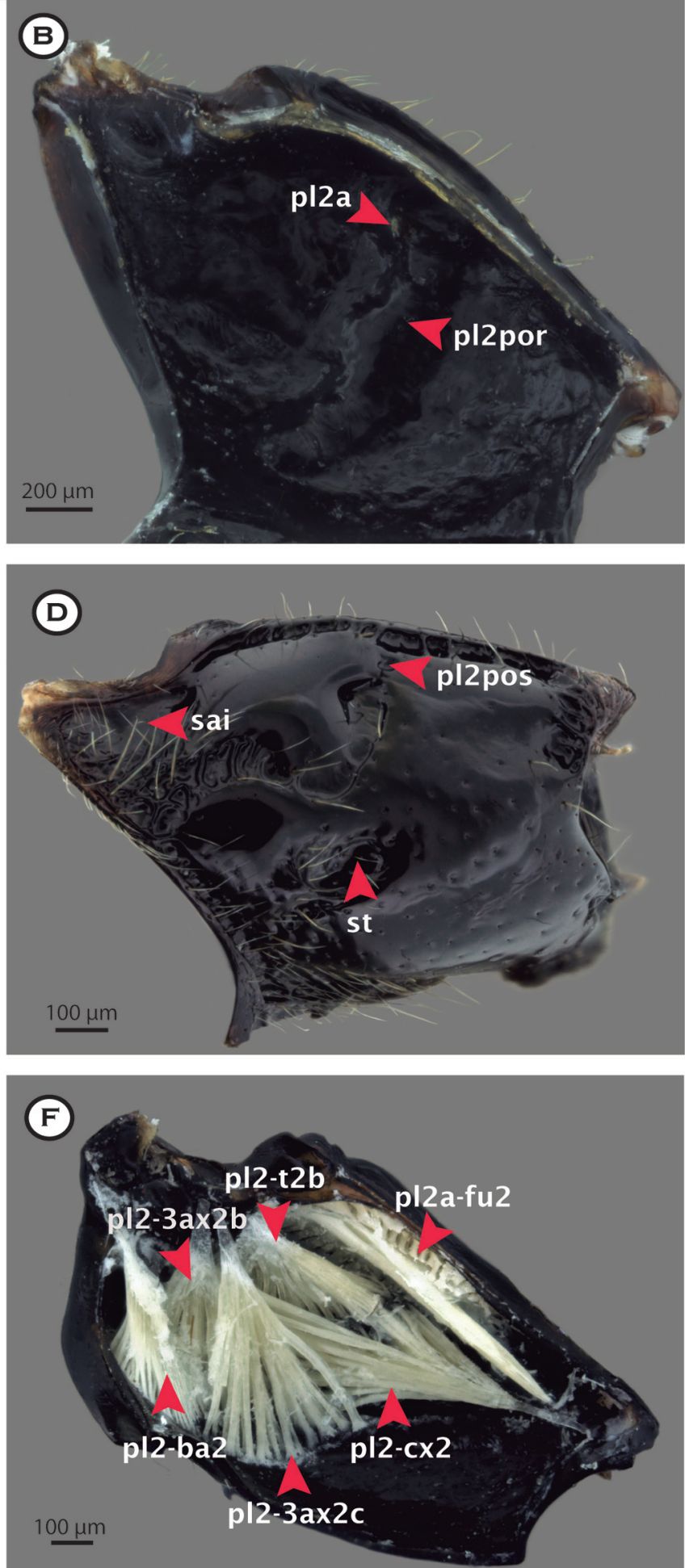

Figure 3. Mesopleuron. (A-B) Dissomphalus. (C) Prosierola. (D) Cleistepyris. (E) Pseudisobrachium. (F) Epyris. (A, C, D) lateral view. (B, E, F) internal view. Abbreviations: $\mathrm{pl} 2 \mathrm{pos}=$ posterior oblique sulcus of the mesopleuron; $\mathrm{sps}=$ subpleural signum; $\mathrm{pl} 2 \mathrm{a}=$ mesopleural apodeme; $\mathrm{pl} 2 \mathrm{por}=$ posterior oblique ridge of the mesopleuron; saa = subalar area; sai = subalar impression; $\mathrm{pl} 2 \mathrm{p}=$ mesopleural pit; $\mathrm{st}=$ sternaulus; $\mathrm{pl2}$-ba2 = mesopleuron-mesobasalar; pl2-3ax2b= second mesopleuro-third axillary sclerite of forewing muscle; $\mathrm{pl} 2-3 \mathrm{ax} 2 \mathrm{c}=$ third mesopleuro-third axillary sclerite of forewing muscle; $\mathrm{pl} 2$-t2 $\mathrm{b}=$ second mesopleuro-mesonotal muscle; pl2-cx2 = mesopleuro-mesocoxal muscle; pl2a-fu2 = anterior mesopleuro-mesofurcal muscle. 
Posterior oblique sulcus of the mesopleuron (pl2pos: Figs. 1F, 3A, D) = Oblique sulcus arising close to mesopleural pit, which follows to the anteroventral direction (Lanes et al., 2020). Criterion 1.

longitudinal groove (or **sillon longitudinal) by Kieffer (1910); Muesebeck (1934).

mesopleural sulcus by Barbosa \& Azevedo (2011c, 2012). oblique espisternal sulcus by Argaman (2003).

oblique groove (or **illon oblique) by Benoit (1956, 1957,

1968); Evans (1964, 1966a); Kieffer (1908).

oblique mesopleural sulcus by Vilhelmsen et al. (2010). posterior oblique sulcus of the mesopleuron by Barbosa \&

Azevedo (2016); Lanes et al. (2020); Richards (1956).

posterior oblique suture by Richards (1956); Shcherbakov (1981).

transversal furrow by Gobbi \& Azevedo (2016).

transverse groove by Argaman (1990); Barbosa \& Azevedo (2011c).

Posterior subalar pit (psup: Fig. 1B) = The pit located posterodorsally on the mesopectus corresponding to the posterodorsal edge of the mesopleuron (HAO_0000961). Criterion 1.

posterior subalar pit by Ronquist \& Nordlander (1989). subalar pit Gibson (1985); Karlsson \& Ronquist (2012);

Krogmann \& Vilhelmsen (2006); Lanes et al. (2020); Michener (1944); Mikó et al. (2007); Vilhelmsen et al. (2010).

Posterodorsal edge of the mesopleuron (pdem: figs. 12, 108 in Mikó et al., 2007) = The edge located at the intersection of the mesepimeral ridge and the inflected dorsal margin of the mesopleuron (HAO_0000771). Criterion 1.

posterodorsal edge of the mesopleuron by Lanes et al. (2020); Mikó et al. (2007).

process on mesepimeral ridge by Ronquist \& Nordlander (1989).

Sternaular elevation (ste: Fig. 2D) = Internal elevation of the mesopleuron corresponding to the sternaulus externally $(*)$.

Sternaulus (st: Figs. 2C, 3D) = The line or fovea marking the site of origin of the mesopleuro-mesobasalar muscle* (HAO_0000953). Criterion 1.

sternaulus by Castro et al. (2011); Lanes et al. (2020); Wharton (2006).

sub-anterior fovea by Alencar \& Azevedo (2011a); Stein et al. (2011).

Subalar area (saa: Fig. 3C) = The area delimited by the mesepimeral inflection, corresponding to the subalar ridge externally, which bears the mesopleural wing process (HAO_0000960). Criterion 1. subalar area by Karlsson \& Ronquist (2012); Lanes et al. (2020); Michener (1944); Ronquist \& Nordlander (1989).

subtegular plate by Linsley \& Michener (1939).

Subalar impression (sai: Figs. 2C, 3C) = Depression anterodorsal of the mesopleuron that generally is posteriorly connected to the mesepimeral sulcus (Lanes et al., 2020). Criterion 1.

acropleural fovea by Barbosa \& Azevedo (2014a). acropleural sulcus by Barbosa \& Azevedo (2014a, b, 2015, 2016); Barbosa et al. (2017); Vilhelmsen et al. (2010). sub-alar fovea by Barbosa \& Azevedo (2009, 2010, 2011a); Lim et al. (2010). subalar impression by Karlsson \& Ronquist (2012); Lanes et al. (2020).

subtegular fovea by Azevedo (2011); Azevedo \& Alencar (2010b); Azevedo \& Barbosa (2010); Azevedo \& Lanes (2009); Barbosa \& Azevedo (2011b, c, 2012). subtegular furrow by Ramos \& Azevedo (2012); subtegular groove by Alencar \& Azevedo (2009, 2011a, b); Alencar et al. (2016); Azevedo (2014); Azevedo \& Alencar (2009, 2010a); Azevedo \& Mugrabi (2014); Azevedo et al. (2018a, b); Lanes \& Azevedo (2007, 2008); Lim \& Azevedo (2014); Lim \& Lee (2013). sub-tegular groove by Waichert \& Azevedo (2009). subtegular groove of mesopleuron by Lanes \& Azevedo (2008). subtegular mesopleural fovea by Azevedo (2014).

Subalar tubercle (sat: see fig. 5A in Karlsson \& Ronquist (2012)) = The projection located posteriorly on the subalar area, which accommodates the posterior end of the second axillary sclerite of the forewing at the beginning of the upstroke of the wing (HAO_0001475). Criterion 1.

cup-shaped socket on pleuron by (HAO). subalar tubercle by Karlsson \& Ronquist (2012).

Subpleural signum (sps: Figs. 3A, C) = The signum located submedially on the ventral face of the mesopleuron, which corresponds to the site of origin of the first mesopleuro-mesonotal (pl2-t2a) muscle (HAO_0000975). Criterion 3.

precoxal sulcus by Richards (1956). precoxal suture by Richards (1956). subpleural signum by Lanes et al. (2020); Michener (1944); Vilhelmsen et al. (2010).

Upper mesopleural fovea (pl2uf: Figs. 1D, E) = Fovea located centrally in the mesopleura around the mesopleural pit (Lanes et al., 2020). Criterion 1.

mesopleural fovea by Alencar \& Azevedo (2009, 2011b); Azevedo \& Alencar (2010a); Azevedo \& Barbosa (2010); Azevedo \& Lanes (2009); Azevedo \& Mugrabi 
(2014); Barbosa \& Azevedo (2010, 2011a, b); Evans (1966b, 1969c); Lim \& Lee (2013); Lim et al. (2010); Stein \& Azevedo (2007); Stein et al. (2011); Vargas \& Azevedo (2016a); Waichert \& Azevedo (2009); Zamprogno \& Azevedo (2014).

oval fovea by Cameron (1905).

pleural fovea by Gordh \& Witethom (1995).

upper fovea (or **fóvea superior) by Rosmann \& Azevedo

(2005); Waichert \& Azevedo (2009).

upper mesopleural fovea by Lanes et al. (2020).

\section{Musculature}

Anterior mesopleuro-mesofurcal muscle (pl2a-fu2: Figs. 2D, 3F) = The mesofurcal muscle that originates at the mesopleuron and inserts distally on the mesofurca (HAO_0000118).Criterion 1.

anterior mesopleuro-mesofurcal muscle by Vilhelmsen et al. (2010).

mesopleuro-mesofurcal muscle by Mikó et al. (2007).

First mesopleuro-mesonotal muscle (pl2-t2a: http:// api.hymao.org/public/figure/show zoom/8424 in HAO) = The mesonotal muscle that arises ventrally from the mesopectus and inserts on the mesoscutum laterally of the notauli and medially parascutal carina (HAO_0000332).

first mesopleuro-mesonotal muscle by Mikó et al. (2007); Vilhelmsen et al. (2010); Willsch et al. (2020).

Mesocoxo-mesosubalar muscle (cx2-sa2: Fig. 2B) = The mesosubalare muscle that arises from the mesocoxa and inserts on the mesosubalare (HAO_0000544). Criterion 2.

mesocoxo-mesosubalar muscle by Mikó et al. (2007);

Vilhelmsen et al. (2010); Willsch et al. (2020).

mesocoxo-mesosubalare muscle by Mikó et al. (2007).

Mesopleuro-mesobasalar muscle (pl2-ba2: Figs. 3E, F) = The mesobasalar muscle that originates anteroventrally at the mesopleuron and inserts on the mesobalare (HAO_0000563). Criterion 1.

mesopleural-basalare muscle by Wharton (2006). mesopleuro-mesobasalar by Vilhelmsen et al. (2010). mesopleuro-mesobasalar muscle by Willsch et al. (2020). mesopleuro-mesobasalare muscle by Mikó et al. (2007).

Mesopleuro-mesocoxal muscle (pl2-cx2: Figs. 2E, 3F) = The mesocoxal muscle that arises from the mesopleuron and inserts on the mesocoxa (HAO_0000564). Criterion 1.

basalar muscle of the mesothorax by Snodgrass (1942). mesopleuro-mesocoxal by Willsch et al. (2020).

mesopleuro-mesocoxal muscle by Mikó et al. (2007);

Willsch et al. (2020); Vilhelmsen et al. (2010).
Prepecto-mesobasalar muscle (pre-ba2: http:// api.hymao.org/public/figure/show zoom/8930 in HAO) $=$ The mesobasalar muscle that arises from prepectus (HAO_0001805).

prepectus mesobasalar Vilhelmsen et al. (2010).

Second mesopleuro-mesonotal muscle (p/2-t2b: Figs. $\mathbf{3 E}, \mathbf{F})=$ The mesonotal muscle that arises medially from mesopleuron and inserts on the ventral surface of the lateral axillar area (HAO_0000924). Criterion 1.

second mesopleuro-mesonotal muscle by Mikó et al.

(2007); Willsch et al. (2020).

second mesopleuro-mesonotal by Vilhelmsen et al. (2010).

Second mesopleuro-third axillary sclerite of forewing muscle (pl2-3ax2b: Figs. 3E, F) = The fore wing third axillary muscle that arises anteroventrally from the mesopleuron (HAO_0001742). Criterion 1.

anterior mesopleuro-third axillary sclerite of forewing by Mikó et al. (2007); Vilhelmsen et al. (2010).

second mesopleuro-third axillary sclerite of forewing by Vilhelmsen et al. (2010).

second mesopleuro-third axillary sclerite of forewing muscle by Willsch et al. (2020).

Third mesopleuro-third axillary sclerite of forewing muscle (pl2-3ax2c: Figs. 3E, F) = The fore wing third axillary muscle that originates posterolaterally from the mesopleuron (HAO_0001214). Criterion 1.

posterior mesopleuro-third axillary sclerite of forewing muscle by Mikó et al. (2007).

third mesopleuro-third axillary sclerite muscle by Vilhelmsen et al. (2010).

third mesopleuro-third axillary sclerite of forewing by Willsch et al. (2020).

\section{Axillary sclerites}

First axillary sclerite of the forewing (1ax2: fig. 44 in Gibson, 1986) = The axillary sclerite that articulates anteriorly and medially with the anterior notal wing process laterally with the second axillary sclerite, and posteriorly with the posterior notal wing process (HAO_0001772). Criterion 1.

first axillary sclerite by Gibson (1986); Ronquist \& Nordlander (1989); Snodgrass (1909).

first axillary sclerite of the forewing by Lanes et al. (2020).

Mesobasalare (ba2: figs. 9, 10, 12-16 in Gibson, 1985) = The basalare located in the mesothorax (HAO_0000542).

mesobasalare by Lanes et al. (2020); Mikó et al. (2007). 
Mesosubalare (sa2: http://api.hymao.org/public/figure/show zoom/16875 in HAO) = The subalare located in the mesothorax (HAO_0000581).

mesosubalare by Lanes et al. (2020); Mikó et al. (2007).

Second axillary sclerite of the forewing (2ax2: fig. 44 in Gibson, 1986) = The second axillary sclerite that is located on the mesothorax (HAO_0001673). Criterion 1.

second axillary sclerite by Gibson (1986); Snodgrass (1909).

second axillary sclerite of the forewing by Lanes et al. (2020).

Third axillary sclerite of the forewing (3ax2: fig. 44 in Gibson, 1986) = The third axillary sclerite that is located on the mesothorax (HAO_0001632). Criterion 1.

third axillary sclerite by Gibson (1986).

third axillary sclerite of the forewing by Lanes et al. (2020).

\section{DISCUSSION}

As proposed by Freixa (2006), denominative variation in terminology responds to linguistic needs of different natures, being that they occur in a natural way and, sometimes, they can result from the enhancement about the interpretation of the studied objects (evolution of concepts). However, contrary to what was defended by Alves (2000) and Martins (2015), we believe that, in some cases, the presence of synonyms, homonyms and polysemies can be considered problematic in specialized communication, especially when different denominations for the same concept are a product of imprecise and/or ambiguous definitions of conceptual boundaries (i.e., denominative variation caused by conceptual imprecision; see cognitive causes in Freixa, 2006).

Based on the morphological analysis of several Bethylidae taxa and their respective descriptions and terminologies adopted, we verify that over the years, a large number of imprecise terms have been proposed to name the same mesopleural characters applied to Bethylidae or even to Hymenoptera. We believe that the huge number of terminological synonyms presented in the anatomical glossary can be evidence of that.

Many terms are not identified due to the conceptual imprecision regarding the structure to which it was referring, usually caused by incomplete descriptions and lack of illustrations. Among the characters identified, many are difficult to interpret and the factors that contribute to this are: the structural equivalence between the structure is difficult to establish, the lack of knowledge about what it represents morphologically and the lack of a clear delimitation of the structures in some cases (e.g., subalar impression, mesepimeral sulcus, sternaulus). Moreover, many areas and characters are little explored in taxonomic and cladistic contexts (e.g., anterior and posterior subalar pit, sternaulus, mesopleural epicoxal lobe and subalar area).

\section{Synonymous and polysemous terms}

In this topic we will discuss the main cases of the synonymous and polysemous terms found in Bethylidae literature (mainly) and, in some cases, groups of Hymenoptera.

In Bethylidae, the posterior oblique sulcus of the mesopleuron is present in Pristocerinae and Mesitiinae, and despite showing little variation in size, position and format, it has been labelled differently in both subfamilies (see Argaman, 2003; Barbosa \& Azevedo, 2011a, b; 2012; Gobbi \& Azevedo, 2016).

The use of names such as mesopleural sulcus (see Barbosa \& Azevedo, 2011c; 2012), for example, can lead to misidentification with another sulcus present in the mesopleuron e.g., sometimes, the lower margin of the mesopleural fovea form a structure like a sulcus externally. Names such as transversal furrow (see Gobbi \& Azevedo, 2016) and other terms present in Bethylidae literature can make identification by systematists difficult, because in the name there is no inference about the location of the character, making it difficult to correlate the name and the structure it represents through literature, especially when interpreted by non-specialists in Bethylidae. Furthermore, this sulcus is also found in other Hymenoptera groups, e.g., Chrysididae and Pompilidae, and was termed posterior oblique sulcus of the mesopleuron by Richards (1956), the same term established in Bethylidae as described by Lanes et al. (2020).

Establishing the correspondence of the structure can be difficult, even when there is little structural variation, as the mesopleural callus. This area was named by Evans (1961) as "a more or less well defined swelling just below the base of the hind wings"to the genus Pseudisobrachium that belongs to Pristocerinae. Because of this, the term was widely used in workers of this subfamily. However, in some genera of the Epyrinae, this area is more accentuated, which took Alencar \& Azevedo (2013) to name it as upper mesopleural elevation. Lanes et al. (2020) standardized the term acropleural area to this region, but our muscular analysis is in disagreement with the definition presented by them (see definition proposed by Lanes et al. (2020) and our definition in the glossary section). Because of this, we will keep the term mesopleural callus (as proposed by Evans (1961), but with a new conception. This terminological unification based on an anatomic study will make the works in Bethylidae safer and more understandable and it can serve as an area to be explored and studied in other groups of Hymenoptera.

The subalar impression has recently been proposed for Bethylidae and it has received many terms. Externally, this structure is fused posteriorly with mesepimeral sulcus, being considered and named as a single structure in the publications of the Bethylidae. Therefore, the terms found in the literature review refers to the subalar impression and part of the mesepimeral sulcus. Of all citations of this term, only the publications by Barbosa \& Azevedo (2014a, b; 2015; 2016), and Barbosa et al. (2017) seem to have followed the original proposition of Gibson (1986), which used the term acropleural sulcus to this area. 
The problems related to the terminology of the mesepimeral sulcus arises mainly from the lack of the knowledge and the misinterpretation of the type of structure it represents, whether a groove (e.g., episternal groove and mesopleural groove), suture (e.g., mesepimeral suture) or carina (e.g., postpectal carina) that do not represent the structure, more complete definitions and names about the structures can be found in Lanes et al. (2020), Ronquist \& Nordlander (1989) and HAO. Despite these terms, the names mostly used in Bethylidae are episternal furrow and episternal groove, which was cited for the first time by Azevedo (2008a) and Barbosa \& Azevedo (2010). However, they did not define the term.

The mesopleural pit is an example of the lack of uniformity in terminology not just in Bethylidae, but also in other families of Hymenoptera (e.g., episternal scrobe to bees - Michener (1944); pleural apophysis to bees Snodgrass (1942); mesopleural scrobe to Braconidae Karlsson \& Ronquist (2012); pleural pit Platygastroidea - Mikó et al. (2007)). Although there are no doubts about the identity of the mesopleural pit, several terms have been applied to this structure, which shows the importance in using the uniform terminology in taxonomy, cladistic and morphologic works. To adopt this practice can make the use of data from the literature more reliable and less laborious.

The lack of consistent criteria for proposing primary homologies (sensu De Pinna, 1991) may be one of the factors that promotes proliferation of terminological polysemy or synonyms. Even when there is concern with the proposal of homologies through comparative anatomy, the superficial analysis of the characters is not always sufficient, since some of them may be externally similar, but internally they represent totally different structures. An example of the lack of the consistent criteria is the case of the "transepisternal line". Lanes et al. (2020) used the term "transepisternal line" to name a ventral sulcus of the lateral surface of the mesopleuron, but for Gibson (1985) the "transepisternal line" marks the origin of muscles that does not originate from this sulcus, which, in fact, appears to be only the inferior margin of the lower mesopleural fovea.

Many works, mainly taxonomic, prioritize the description of the specimens, with no concern for recognizing whether the analyzed characters have already been described in other taxa that do not belong to the group of the study, which leads to the creation of new terms for such characters. In addition, terminological polysemy or synonyms may be the result of a lack of extensive research on the terminology (e.g., databases such as HAO and Antkey) and of the different motivations by systematics and morphologists. Thus, the stability in terms requires agreement as to which terms should be used to name the structures without affecting the scientific communication (Gibson, 1993).

The "subalar pit" is an example of the importance in agreement between systematics and morphologists. The mesopleuron has two small pits in the subalar region, anterior and posterior, however, in some taxa only one of the pits is present, so that Richards (1956) used the term "subalar pit" to name the anterior subalar pit, whereas Gibson (1985) used the same term to name the posterior subalar pit.

\section{Poorly explored characters}

The study of the mesopleuron showed not only the large number of synonyms existing for its structures, but also revealed many little explored characters that can be useful in systematics.

Some of them are certainly under-explored because of the location and size of the structure, e.g., the anterior subalar pit, posterior subalar pit, subalar area and mesepimeral lobe. All of them are located at the anterior extremity of the mesopleuron, and are often difficult to observe because the wing generally covers them. They are small compared to other structures. In these cases, the state of preparation of the specimen can greatly influence observability, because the position of the wing can not only make it difficult to observe, but to correctly identify and interpret the structures. Thus, this area of mesopleuron probably is neglected due to the uncertainty of their homology, or because of the risk of damage to the specimen while studying them.

However, sternaulus and epicoxal mesopleural lobe are easy to observe, but little investigated in Bethylidae. The sternaulus, for example, was mentioned only three times for Bethylidae, as sub-anterior fovea by Alencar \& Azevedo (2011a) and Stein et al. (2011) and sternaulus by Lanes et al. (2020). The mesopleural epicoxal lobe was mentioned only once by Ramos \& Azevedo (2012). In our study we observed that these structures vary considerably and can be useful for the taxonomy of the group, as well as Hymenoptera.

Although we did not used any specific methodology to explicitly evaluate character usage throughout the literature, we believe that the little use of them may be related to some factors: (i) researchers generally follow standardized descriptions previously adopted, without considering their inherited descriptive and/or explanatory limitations for particular groups; (ii) researchers explore only a fixed set of characters determined by their historical usage in a particular group; and (iii) specialized literature that provides explicit information and explanation of characters is virtually absent for a particular group.

\section{Negative effects of the absence of uniform terminology}

The lack of a specific literature and the wide range of morphological variability lead specialists of different taxonomic groups to develop their terminologies independently, without standardized vocabularies, which generates many synonyms (Gibson, 1985; Seltmann et al., 2013). This may result in the accumulation of terms that often are confusing or that do not represent the structure and uncertain homology, making the taxonomic 
and cladistic work mostly ineffective and constitutes a barrier to clear and accurate scientific communication.

According to Komarek \& Beutel (2006) insufficient morphological knowledge of the characters can result in imprecise or inadequate observations, and important features may be overlooked or misinterpreted. This shows the importance of morphological knowledge and consequently terminological standardization in a taxonomic context, especially to new taxonomists. At the beginning of their careers, many of them are unable to have a clear understanding of some structures, may replicate any eventual error or find the work dull and difficult, especially for under-studied taxonomic groups.

For cladistic analysis, the effects on the lack of uniformity of terminology can result in a character matrix with many problems, because the incorrect identification of the structure may not correspond to the primary hypotheses of homology. Examples of this problem can be found at Waichert \& Azevedo (2009) and Alencar \& Azevedo (2013). In the first situation, the term subtegular groove is used in their matrix of the characters, but it corresponds to two distinct structures, the subalar impression and mesepimeral sulcus, which are not delimited externally, and, therefore, seem to form a single structure. In the second situation, the terms supra-posterior callus and posterior elevation on upper fovea in Alencar \& Azevedo (2013), are used to name the same structure, present in different groups that is the mesopleural callus.

Furthermore, in groups with sexual dimorphism, some structures are difficult to correlate. Thus, the standardization of terms and determination of homologous regions among species is important to infer phylogenetic relationships (Gibson, 1986).

\section{CONCLUSION}

The study of the mesopleuron of bethylids showed how much a study of certain regions of the body is necessary and how much it can not only add new characters, but also understanding about certain structures. The standardization of the terminology of the mesopleural structures will facilitate the study of the mesopleuron of Bethylidae, generating uniformity in future studies, which can serve for comparison and understanding not only within the family, but in other groups.

Even understanding the importance of terminological variation, especially when it relates to the improvement of concepts, we believe that the standardization of terminologies should be managed with due care, respecting recommended standards and established by consensus, considering terminological variation as part of the process.

Thereby, the efforts of The Hymenoptera Anatomy Ontology (HAO) and many other morphological studies have contributed to reducing the problem related to this subject. Gibson (1993) stated that systematics and morphology are inextricably related because each is dependent on the other for its own success, which is increasingly necessary.

\section{ACKNOWLEDGMENTS}

We thank the curators of the collections for authorization to use the analyzed specimens. We thank Ricardo Kawada for loaning specimens for study. We thank the Estação Biológica de Santa Lúcia for allowing us to collect specimens used in this study. We are also very grateful to the subject editor Helena Onody and reviewers Lars Vilhelmsen and anonymous for the revision and suggestions regarding the manuscript. The first author was supported with a Ph.D. bursary of Demanda Social by CAPES (Coordenação de Aperfeiçoamento de Pessoal de Nível Superior); third author was supported with a bursary by CNPq (Conselho Nacional de Desenvolvimento Científico e Tecnológico), INCT-CNPq HymPar grant \# 303748/2018-4.

\section{AUTHORS' CONTRIBUTIONS}

C.D.B.: carried out all laboratory steps including taking and editing images, revised the literature, and wrote the manuscript. G.O.L.: wrote the manuscript, defined the scope of this research. C.O.A.: wrote the manuscript and assisted standardization.

\section{REFERENCES}

Agosti, D. \& Johnson, N.J. 2005. Antbase. World Wide Web electronic publication. Available: http://antbase.org. Access: 08/02/2021.

Alencar, I.D.C.C. \& Azevedo, C.0. 2009. Rediscovery of Planepyris Kieffer: A new synomym of Trachepyris Kieffer, (Hymenoptera, Bethylidae). Doriana, 8: 1-12.

Alencar, I.D.C.C. \& Azevedo, C.0. 2011a. Review of Neurepyris Kieffer, 1905 (Hymenoptera, Bethylidae), a new synonym of Pristocera Klug, 1808. European Journal of Taxonomy, 4: 1-12.

Alencar, I.D.C.C. \& Azevedo, C.0. 2011b. Revision of Malagasy Odontepyris Kieffer (Hymenoptera, Bethylidae). Zootaxa, 2935: 26-40.

Alencar, I.D.C.C. \& Azevedo, C.0. 2013. Reclassification of Epyrini (Hymenoptera: Bethylidae): a tribal approach with commentary on their genera. Systematic Entomology, 38: 45-80.

Alencar, I.D.C.C.; Colombo, W.D. \& Azevedo, C.0. 2016. Pristocera masii: rediscovery of the holotype and its transfer to Acrepyris (Hymenoptera: Bethylidae). Acta Entomologica Musei Nationalis Pragae, 56(2): 795-803.

Alves, I.A. 2000. Polissemia e homonímia em uma perspectiva terminológica. Alfa, Revista de Linguistica, 44: 261-272. https://periodicos.fclar.unesp. br/alfa/issue/view/300.

Argaman, Q. 1990. Generic synopsis of Sierolomorphidae (Hymenoptera). Israel Journal of Entomology, 24: 29-33.

Argaman, Q. 2003. Generic synopsis of Mesitinae Kieffer, 1914 (Hymenoptera: Bethylidae). Entomofauna, 24: 61-95.

Azevedo, C.0. 1992. Sobre os Rhabdepyris Kieffer (Hymenoptera, Bethylidae) coletadas em Piçarras, SC, Brasil. Revista Brasileira de Entomologia, 36 : 251-254.

Azevedo, C.0. 1994. Descriptions of two new species and notes on the genus Bakeriella Kieffer from Brazil and Ecuador (Hymenoptera, Bethylidae). Journal of Hymenoptera Research, 3: 145-150.

Azevedo, C.0. 1999a. Additions to the Neotropical Epyrinae (Hymenoptera, Bethylidae), with description of a new species of Lepidosternopsis from Brazil. Iheringia, Série Zoológica, 87: 11-18. 
Azevedo, C.0. 1999b. Additions to the systematic of the bethylid fauna (Hymenoptera, Chrysidoidea) from Chile. Revista Brasileira de Zoologia, 16(1): 233-243.

Azevedo, C.0. 1999c. On the Neotropical Rhabdepyris Kieffer (Hymenoptera Bethylidae) of the genus Chlorepyris. Revista Brasileira de Zoologia, 16(3): 887-897. D0I

Azevedo, C.0. 2004. A new species of Caloapenesia from Vietnam with discovery of the female of the genus. Spixiana, 27(2): 143-146.

Azevedo, C.0. 2005. A new species of Allobethylus (Hymenoptera, Bethylidae) from Australia, with a key to world species. Zootaxa, 1064: 25-30.

Azevedo, C.0. 2006. Two new genera of Sclerodermini (Hymenoptera, Bethylidae, Epyrinae) with large scolebythid-like prostenums. Zootaxa, 1191: 35-47.

Azevedo, C.0. 2007. The Provancher types of Bethylidae (Hymenoptera, (hrysidoidea). Boletim do Museu Biológico Mello Leitão, 22: 57-67.

Azevedo, C.0. 2008a. Characterization of the types of the Neotropical Pseudisobrachium (Hymenoptera, Bethylidae), with a key to species. Revista Brasileira de Zoologia, 25(4): 737-801. DOI

Azevedo, C.0. 2008b. Synopsis of Prosierola (Hymenoptera: Bethylidae). Zootaxa, 1912: 45-58.

Azevedo, C.0. 2009a. A new species of Solepyris Azevedo (Hymenoptera, Bethylidae) from Brazil, with amended diagnosis of the genus. Revista Brasileira de Entomologia, 53(3): 327-330. DOI

Azevedo, C.0. 2009b. Synopsis of Lytopsenella Kieffer (Hymenoptera: Bethylidae). Zootaxa, 2286: 58-64.

Azevedo, C.0. 2011. Synopsis of Aspidepyris Evans, 1964 (Hymenoptera, Bethylidae). Zootaxa, 3016: 63-68.

Azevedo, C.0. 2014. Synopsis of Bakeriella Kieffer, 1910 (Hymenoptera, Bethylidae). Zootaxa, 3878: 501-535. D0I

Azevedo, C.0. \& Alencar, I.D.C.C. 2009. Rediscovery of Pristepyris Kieffer (Hymenoptera, Bethylidae), a new synonym of Acrepyris Kieffer. Zootaxa, 2287: 45-54.

Azevedo, C.0. \& Alencar, I.D.C.C. 2010a. Rediscovery of the Afrotropical genus Trissepyris Kieffer (Hymenoptera, Bethylidae), a new synonym of Epyris Westwood. Journal of Afrotropical Zoology, 6: 3-7.

Azevedo, C.0. \& Alencar, I.D.C.C. 2010b. Rediscovery of Melanepyris (Hymenoptera: Bethylidae): a new synonym of Epyris. Revista Brasileira de Zoologia, 27(3): 403-407. DOI

Azevedo, C.0. \& Barbosa, D.N. 2010. Two new species Pararhabdepyris Gorbatovskii (Hymenoptera, Bethylidae) from Australia and Thailand. Zootaxa, 2668: 55-62.

Azevedo, C.0. \& Lanes, G.0. 2009. Cladistic assessment and redescription of Galodoxa torquata Nagy (Hymenoptera, Bethylidae), a striking species with swallow tailed metasomal sternite. Zoologische Mededelingen Leiden, 83(4): 841-851.

Azevedo, C.0. \& Mugrabi, D.F. 2014. Three new species of Tuberepyris Lanes et Azevedo (Hymenoptera, Bethylidae), with amended diagnosis of the genus. Zootaxa, 3794: 556-564.

Azevedo, C.0.; Alencar, I.D.C.C. \& Colombo, W.D. 2018a. Pairs in copulation of the highly dimorphic genus Pristocera Klug (Hymenoptera, Bethylidae) from Madagascar solve taxonomic problems of male-female associations. Zootaxa, 4433: 1-49.

Azevedo, C.0.; Alencar, I.D.C.C.; Ramos, S.M.; Barbosa, D.N.; Colombo, W.D.; Vargas-R., J.M. \& Lim, J. 2018b. Global Guide of the flat wasps (Hymenoptera: Bethylidae). Zootaxa, 4489: 1-294.

Azevedo, C.0.; van Noort, S. \& Notton, D.G, 2018c. Rediscovery of Disepyris semiruber (Kieffer) (Hymenoptera: Bethylidae) in Southern Africa, with first description of its male. Journal of Natural History, 52: 23-24

Azevedo, C.0.; Moreira, A.R. \& Kawada, R. 2005. Taxonomia de Bakeriella (Hymenoptera, Bethylidae) da Bolívia. Iheringia, Série Zoológica, 95(2): 165-172.
Barbosa, D.N. \& Azevedo, C.0. 2009. Laelius Ashmead (Hymenoptera, Bethylidae) from Madagascar, with description of two new species. Zootaxa, 2170: 1-14.

Barbosa, D.N. \& Azevedo, C.0. 2010. Order Hymenoptera, family Bethylidae, genus Laelius. In: van Harten, A. (Ed.). Arthropod Fauna of UAE. Abu Dhabi, Dar Al Ummah Printing. v. 3, p. 412-421.

Barbosa, D.N. \& Azevedo, C.0. 2011a. Phylogeny and reclassification of Laelius (Hymenoptera, Bethylidae) and description of four new species. Insect Systematics \& Evolution, 42: 237-275.

Barbosa, D.N. \& Azevedo, C.0. 2011b. Taxonomy of Allobethylus Kieffer (Hymenoptera, Bethylidae) from southeastern Asia. Journal of AsiaPacific Entomology, 14: 89-94.

Barbosa, D.N. \& Azevedo, C.0. 2011c. Order Hymenoptera, family Bethylidae, subfamily Mesitiinae. In: van Harten, A. (Ed.). Arthropod Fauna of UAE. Abu Dhabi, Dar Al Ummah Printing. v. 4, p. 375-404.

Barbosa, D.N. \& Azevedo, C.0. 2012. Revision of Mesitiinae (Hymenoptera, Bethylidae) from Madagascar, with description of eleven species. Zootaxa, 3417: 1-44.

Barbosa, D.N. \& Azevedo, C.0. 2014a. Revision of the Neotropical Laelius (Hymenoptera: Bethylidae) with notes on some Nearctic species. Zoologia, 31: 285-311.

Barbosa, D.N. \& Azevedo, C.0. 2014b. Moczariella, a bizarre new genus of Mesitiinae (Hymenoptera, Bethylidae) from Arab Peninsula. Zootaxa, 3860: 291-297.

Barbosa, D.N. \& Azevedo, C.0. 2015. Synopsis of Bradepyris Kieffer, 1905 (Hymenoptera, Bethylidae, Mesitiinae). European Journal of Taxonomy, 151: 1-16. DOI

Barbosa, D.N. \& Azevedo, C.0. 2016. Australomesitius gen. nov. (Hymenoptera, Bethylidae: Mesitiinae), an unexpected new genus from Australia. Zootaxa, 4061: 447-450.

Barbosa, D.N.; Kawada, R. \& Azevedo, C.0. 2014. Order Hymenoptera, family Bethylidae. Genus Israelius, Richards, 1952. In: van Harten, A. (Ed.). Arthropod Fauna of UAE. Abu Dhabi, Department of the President's Affairs. v. 5, p. 463-470.

Barbosa, D.N.; Kawada, R. \& Azevedo, C.0. 2017. Order Hymenoptera, family Bethylidae. Genus Glenosema, Kiefer. In: van Harten, A. (Ed.). Arthropod Fauna of UAE. Abu Dhabi, Department of the President's Affairs. v. 6, p. 322-335.

Barbosa, D.N.; Perkovsky, E.E. \& Azevedo, C.0. 2013. Two new species of Laelius Ashmead (Hymenoptera: Bethylidae) from Upper Eocene Rovno amber. Neues Jahrbuch fur Geologie und Palaontologie, 267: 67-73. D0I

Benoit, P.L.G. 1952. Bethylidae (Hym.) nord africains nouveaux ou peu connus du Museo Civico di Storia Naturale di Genova. Annali del Museo Civico di Storia Naturale di Genova, 1: 1-7.

Benoit, P.L.G. 1956. Contributions à l'étude de la faune entomologique du Ruanda-Urundi (Mission P. Basilewsky 1953). Hymenoptera: CXII. Bethylidae. Annales Musei Royal du Congo Belge. Tervure. Sciences Geologiques, 51: 560-564.

Benoit, P.L.G. 1957. Hymenoptera - Bethylidae. Exploration du Parc National Albert. Mission G.F. De Witte, 1933-1935. Fascicule 88. Tervuren, Institut des Parcs Nationaux de Congo Belge. 57p.

Benoit, P.L.G. 1968 Contribution à l'étude des espèces africaines du genre Mesitius Spinola (Hym. Bethylidae). Revue de Zoologie et de Botanique Africaines, 77: 83-94.

Biological Spatial Ontology (BSP0). Biological Spatial Ontology: An ontology for representing spatial concepts, anatomical axes, gradients, regions, planes, sides, and surfaces. Available: http://www.obofoundry.org/ ontology/bspo.html. Access: 08/02/2021.

Boudinot, B.E. 2015. Contributions to the knowledge of Formicidae (Hymenoptera, Aculeata): a new diagnosis of the family, the first global 
male-based key to subfamilies, and a treatment of early branching lineages. European Journal of Taxonomy, 120: 1-62.

Cameron, P. 1905. On the phytophagous and parasitic Hymenoptera collected 1995 by Mr. E. Ernest Green in Ceylon. Spolia Zeylanica, 3: 67-97.

Castro, C.; Nunes, J. \& Penteado-Dias, A. 2011. A new species of Heredius Marsh 2002 (Hymenoptera: Braconidae: Doryctinae) from Brazil. Brazilian Journal of Biology, 71: 175-177.

Corrêa, M.S. \& Azevedo, C.0. 2001. Taxonomia de Apenesia (Hymenoptera, Bethylidae) na Reserva Biológica de Duas Bocas, Espírito Santo, Brasil. Iheringia, Série Zoológica, 90: 167-174. DOI

Corrêa, M.S. \& Azevedo, C.0. 2002. Systematics of Epyris (Hymenoptera, Bethylidae) from Reserva Biológica de Duas Bocas, Espírito Santo, Brazil. Revista Brasileira de Entomologia, 46: 129-132. D0I

Corrêa, M.S. \& Azevedo, C.0. 2006. 0 gênero Apenesia (Hymenoptera, Bethylidae) na Mata Atlântica: notas e descrição de sete espécies novas. Revista Brasileira de Entomologia, 50(4): 439-449. DOI

Dahdul, W.M.; Cui, H.; Mabee, P.M.; Mungall, C.J.; Osumi-Sutherland, D.; Walls, R.L. \& Haendel, M.A. 2014. Nose to tail, roots to shoots: spatial descriptors for phenotypic diversity in the Biological Spatial Ontology. Journal of Biomedical Semantics, 5(34): 1-13.

De Pinna, M.C.C. 1991. Concepts and tests of homology in the Cladistic paradigm. Cladistics, 7: 367-394.

Duncan, C.D. 1939. A Contribution to The Biology of North American Vespine Wasps. Stanford University Publications, Biological Sciences, 8: 1-233.

Evans, H.E. 1959. The genus Anisepyris in America North of Mexico (Hymenoptera, Bethylidae). Proceedings of the Entomological Society of Washington, 61: 97-120.

Evans, H.E. 1961. A revision of the genus Pseudisobrachium in the North and Central America (Hymenoptera, Bethylidae). Bulletin of the Museum of Comparative Zoology, 126: 211-318.

Evans, H.E. 1963a. A revision of the genus Pristocera in the Americas (Hymenoptera, Bethylidae). Bulletin of the Museum of Comparative Zoology, 129: 241-290.

Evans, H.E. 1963b. A revision of the Apenesia in the Americas (Hymenoptera, Bethylidae). Bulletin of the Museum of Comparative Zoology, 130: 249-359.

Evans, H.E. 1964. A synopsis of the American Bethylidae (Hymenoptera, Aculeata). Bulletin of the Museum of Comparative Zoology, 132: 1-222.

Evans, H.E. 1965. A revision of the genus Rhabdepyris in the Americas (Hymenoptera: Bethylidae). Bulletin of the Museum of Comparative Zoology, 133: 68-151.

Evans, H.E. 1966a. Further studies on neotropical Pristocerinae (Hymenoptera, Bethylidae). Acta Hymenopterologica, 2: 99-117.

Evans, H.E. 1966b. A revision of the genus Anisepyris Kieffer (Hymenoptera, Bethylidae). Studia Entomologica, 9: 1-120.

Evans, H.E. 1967a. Notes on Mexican and Southwestern U.S. Bethylidae (Hymenoptera): Part I, Pristocerinae. Entomological News, 78: 13-23.

Evans, H.E. 1967b. Notes on Mexican and Southwestern U.S. Bethylidae (Hymenoptera): Part II, Epyrinae. Entomological News, 78: 93-100.

Evans, H.E. 1967c. New generic records of Bethylidae from South America. Proceedings of the Entomological Society of Washington, 69(3): 269-272.

Evans, H.E. 1969a. The genus Pseudisobrachium in Argentina and Chile. Acta Zoologica Liloana, 25: 45-65.

Evans, H.E. 1969b. The genera Apenesia and Dissomphalus in Argentina and Chile (Hymenoptera, Bethylidae). Breviora, 311: 1-23.

Evans, H.E. 1969c. A revision of the genus Epyris in the Americas (Hymenoptera, Bethylidae). Transactions of the American Entomological Society, 95: 181-352.

Evans, H.E. 1970. West Indian wasps of the subfamilies Epyrinae and Bethylinae (Hymenoptera: Bethylidae). Proceedings of the Entomological Society of Washington, 72(3): 340-356.
Evans, H.E. 1973. Further studies on South American Bethylidae (Hymenoptera). Proceedings of the Entomological Society of Washington, 75: 194-204.

Evans, H.E. 1978. The Bethylidae of America North of Mexico. Memoirs of the American Entomological Institute, 27: 1-332.

Freixa, J. 2006. Causes of denominative variation in terminology. A typology proposal. Terminology, 12: 51-77.

Gibson, G.A.P. 1985. Some pro- and mesothoracic structures important for phylogenetic analysis of Hymenoptera, with a review of terms used for the structures. The Canadian Entomologist, 117(11): 1395-1443.

Gibson, G.A.P. 1986. Mesothoracic skeletomusculature and mechanics of flight and jumping in Eupelminae (Hymenoptera, Chalcidoidea: Eupelmidae). The Canadian Entomologist, 118(7): 691-728.

Gibson, G.A.P. 1993. Groundplan structure and homology of the pleuron in Hymenoptera based on a comparison of the skeletomusculature of Xyelidae (Hymenoptera) and Raphidiidae (Neuroptera). Memoirs of the Entomological Society of Canada, 125: 165-187.

Gobbi, F.T. \& Azevedo, C.0. 2006. The Brazilian Holepyris (Hymenoptera, Bethylidae), with description of a new species from Amazonian forest. Zootaxa, 1357: 61-68.

Gobbi, F.T. \& Azevedo, C.0. 2010. Taxonomia de Pseudisobrachium (Hymenoptera, Bethylidae) da Mata Atlântica Brasileira. Revista Brasileira de Entomologia, 54(2): 173-224. DOI

Gobbi, F.T. \& Azevedo, C.0. 2014. Revision of Caloapenesia (Hymenoptera, Bethylidae), with description of sixteen new species. Zootaxa, 3860: 501-535.

Gobbi, F.T. \& Azevedo, C.0. 2016. Revision of Calobrachium Gobbi \& Azevedo, gen. nov. (Hymenoptera, Bethylidae), with description of seven new Oriental species. Zootaxa, 4083: 221-238.

Gordh, G. \& Witethom, B. 1995. A new species of Goniozus from Thailand (Hymenoptera: Bethylidae). Proceedings of the Hawaiian Entomological Society, 32: 145

Gupta, A.; Rajeshwari, S.K. \& Azevedo C.0. 2017. Biology and description of Megaprosternum cleonarovorum sp. nov. (Hymenoptera: Bethylidae) a gregarious larval ectoparasitoid of Cleonaria bicolor Thomson (Coleoptera: Cerambycidae) from India. Zootaxa, 4237: 78-90.

Hymenoptera Anatomy Ontology (HA0). 2020. The Hymenoptera Glossary: Hymenoptera Anatomy Consortium. Available: http://glossary.hymao. org. Access: 05/02/2021.

Karlsson, D. \& Ronquist, F. 2012. Skeletal morphology of Opius dissitus and Biosteres carbonarius (Hymenoptera: Braconidae), with a discussion of terminology. PLoS ONE, 7(4): e32573. D0I

Kawada, R. \& Azevedo, C.0. 2003. New species of Bakeriella (Hymenoptera, Bethylidae) from the New World and new data on geographic distribution. Revista Brasileira de Entomologia, 47(3): 461-468. DOI

Kawada, R. \& Buffington, M. 2016. A scalable and modular dome illumination system for scientific microphotography on a budget. PLOS ONE, 11(5): e0153426. D01

Kawada, R.; Lanes, G.0. \& Azevedo, C.0. 2015. Evolution of metapostnotum in flat wasps (Hymenoptera, Bethylidae): implications for homology assessments in Chrysidoidea. PLOS ONE, 10(10): e0140051. DOI

Kieffer, J.J. \& Marshall, T.A. 1904-1906. Proctotrypides. In: André, E. (Ed.). Species des Hyménoptères d'Europe \& d'Algerie. Tome IX. Paris, Librairie Scientifique A. Hermann. p. 1-55, 21 pls. [Publication dates of the different parts: pages 1-64 $1^{\text {st }}$ January 1904; 65-144 1 1 1 April 1905; $145-2881^{\text {st }}$ November $1905 ; 289-36831^{\text {st }}$ January 1906; 369-551 $1^{\text {st }}$ October 1906].

Kieffer, J.J. 1904. Description de nouveaux Dryininae et Bethylinae du Musée Civique de Gênes. Annali del Museo Civico di Storia Naturale di Genova, Serie 3, 41: 351-412. 
Kieffer, J.J. 1905. Description de nouveaux Proctotrypides exotiques avec une planche et une figure dans le texte. Annales de la Société Scientifique de Bruxelles, 29: 95-142.

Kieffer, J.J. 1906. Description de nouveaux Hyménoptères. Annales de la Société Scientifique de Bruxelles, 30: 113-178.

Kieffer, J.J. 1908. Nouveaux proctotrypides et cynipides d'Amérique recueillis par M. Baker. Annales de la SociétéScientifique de Bruxelles, 32: 7-64.

Kieffer, J.J. 1910. Description de nouveaux microhyménoptères du Brésil. Annales de la Société Entomologique de France, 78: 287-348.

Kieffer, J.J. 1911. Cynipides et Béthylides de I'Afrique du sud (Hymenopt.). Annales de la Société Entomologique de France, 80: 451-462.

Komarek, A. \& Beutel, R.G. 2006. Problems in taxonomy and suggestions for a standardized description of new insect taxa. Entomological Problems, 36: 55-70.

Krogmann, L.\&Vilhelmsen, L. 2006. Phylogeneticimplications of the mesosomal skeleton in Chalcidoidea (Hymenoptera, Apocrita) - Tree searches in a jungle of homoplasy. Invertebrate Systematics, 20: 615-674. DOI

Krombein, K.V. 1992. Systematics of the genera of Epyrinae with ramose male antennae (Hymenoptera: Bethylidae). Proceedings of the Entomological Society of Washington, 94(3): 345-360.

Krombein, K.V. 1996. Biosystematic studies of Ceylonese wasps, XXI: A revision of the Bethylinae and Epyrinae Cephalonomiini and Sclerodermini (Hymenoptera: Bethylidae). Smithsonian Contributions to Zoology, 579: 1-29. D0I

Lanes, G.0. \& Azevedo, C.0. 2007. Redescription and placement of the Oriental Scaphepyris rufus Kieffer (Hymenoptera: Bethylidae). Zootaxa, 1654:55-60.

Lanes, G.0.\& Azevedo, C.0. 2008. Phylogeny and taxonomy of Sclerodermini (Hymenoptera, Bethylidae, Epyrinae). Insect Systematic and Evolution, 39: 55-86. DOI

Lanes, G.0.; Kawada, R.; Azevedo, C.0. \& Brothers, D.J. 2020. Revisited morphology applied for Systematics of flat wasps (Hymenoptera, Bethylidae). Zootaxa, 4752: 1-127.

Leal, M.S. \& Azevedo, C.0. 2001. Taxonomy of Apenesia Westwood (Hymenoptera, Bethylidae) from Paraná, Brazil. Revista Brasileira de Zoologia, 18(3): 673-679.

Lim, J. \& Azevedo, C.0. 2014. Five new species of Disepyris Kieffer, 1905 (Hymenoptera: Bethylidae), with emended generic diagnosis. Zootaxa, 3900: 526-540. DOI

Lim, J. \& Lee, S. 2013. Taxonomy of the family Bethylidae (Hymenoptera: (hrysidoidea) from Cambodia and adjacent countries. I. genus Odontepyris Kieffer (Bethylidae: Bethylinae) with four new species and two new records. Journal of Natural History, 47(31-32): 1-22. D01

Lim, J.; Kwon, H.; Lee, J. \& Lee, S. 2010. A new Laelius species (Hymenoptera: Bethylidae) from (hina with a key to the species in Eastern Palaearctic region. Journal of Asia-Pacific Entomology, 2010: 365-368. D01

Linsley, E.G. \& Michener, C.D. 1939. A generic revision of the North American Nomadidae (Hymenoptera). Transactions of the American Entomological Society, 65: 265-305.

Martins, S.C. 2015. A sinonímia, a polissemia e a homonímia no vocabulário da fauna e da flora. Estudos Linguísticos, 44: 186-207.

Masner, L. 1979. Pleural morphology in scelionid wasps (Hymenoptera, Scelionidae) - an aid to higher classification. The Canadian Entomologist, 111(9): 1079-1087.

Matsuda, R. 1970. Morphology and evolution of the insect thorax. Memoirs of the Entomological Society of Canada, 102 (Suppl. 76): 5-431. D0I

Michener, C.D. 1944. The Social Behavior of the Bees: A Comparative Study. Cambridge, Harvard University Press.

Mikó, I.; Vilhelmsen, L.; Johnson, N.F.; Masner, L. \& Pénzes, Z. 2007. Skeletomusculature of Scelionidae (Hymenoptera: Platygastroidea): head and mesosoma. Zootaxa, 1571: 1-78.
Moreira, A.R. \& Azevedo, C.0. 2003. Taxonomy of Anisepyris (Hymenoptera, Bethylidae) from Estação Biológica de Santa Lúcia, Santa Teresa, ES, Brazil. Boletim do Museu Biológico Mello Leitão, Nova Série, 15: 35-39.

Muesebeck, C.F.W. 1934. Seven new species of Indian Bethylidae (Hymenoptera). Records of the Indian Museum, 36(2): 223-232.

Polaszek, A. \& Krombein, K.V. 1994. The genera of Bethylinae (Hymenoptera; Bethylidae). Journal of Hymenoptera Research, 3: 91-105.

Ramos, M.S. \& Azevedo, C.0. 2009. Sinopse das espécies neotropicais do grupo brasiliensis do gênero Apenesia (Hymenoptera, Bethylidae). Iheringia, Série Zoológica, 99(4): 349-363.

Ramos, M.S. \& Azevedo, C.0. 2012. Revision of Eupsenella Westwood, 1874 (Hymenoptera, Bethylidae). Zootaxa, 3539: 1-80.

Ramos, M.S.; Perkovsky, E.E.; Rasnitsyn, A.P. \& Azevedo, C.0. 2014. Revision of Bethylinae fossils (Hymenoptera: Bethylidae) from Baltic, Rovno and Oise amber, with comments on the Tertiary fauna of the subfamily. Neues Jahrbuch fur Geologie und Palaontologie, 271: 203-228.

Richards, 0.W. 1956. An interpretation of the ventral region of the hymenopterous thorax. Proceedings of the Royal Entomological Society of London, 31: 99-104. D0I

Ronquist, F. \& Nordlander, G. 1989. Skeletal morphology of an archaic cynipoid, Ibalia rufipes (Hymenoptera: Ibaliidae). Entomologica Scandinavica, Supplement 33: 1-60.

Rosmann, W.L. \& Azevedo, C.0. 2005. Dez espécies novas e notas sobre Rhabdepyris Kieffer (Hymenoptera, Bethylidae) da Mata Atlântica. Revista Brasileira de Entomologia, 49(3): 397-408.

Santos, H.S. \& Azevedo, C.0. 2000. Sistemática das espécies de Anisepyris Kieffer, 1905 (Hymenoptera, Bethylidae) do Brasil. Revista Brasileira de Entomologia, 44(3-4): 129-165.

Santos, L.M. dos \& Azevedo, C.0. 2003. Taxonomy of Epyris (Hymenoptera, Bethylidae) from Paraná, Brazil. Iheringia, Série Zoológica, 93(2): 189-195. DOI

Santos, L.M. dos \& Azevedo, C.0. 2008. Taxonomia de Anisepyris Kieffer (Hymenoptera, Bethylidae) da Mata Atlântica Brasileira. Revista Brasileira de Entomologia, 52(3): 328-339. D0I

Sarnat, E.M. \& Suarez, A.V. 2012. Antkey. University of Illinois and Identification Technology Program, CPHST, PPQ, APHIS, USDA. Available: http://www. antkey.org/en. Access: 28/04/2021.

Seltmann, K.C.; Pénzes, Z.; Yoder, M.J.; Bertone, M.A. \& Deans, A.R. 2013. Utilizing descriptive statements from the biodiversity heritage library to expand the Hymenoptera anatomy ontology. PLOS ONE, 8(2): e55674.DOI

Seltmann, K.C.; Yoder, M.J.; Mikó, I.; Forshage, M.; Bertone M.A.; Agosti, D.; Balhoff, J.; Borowiec, M.; Brady, S.; Broad, G.; Brothers, D.; Burks, R.; Buffington, M.; Campbell, H.; Dew, K.; Ernst, A.; Fernandez-Triana, J.; Gates, M.; Gibson, G.; Jennings, J.; Johnson, N.; Karlsson, D.; Kawada, R.; Krogmann, L.; Kula, R.; Ohl, M.; Rasmussen, C.; Ronquist, F.; Schulmeister, S.; Sharkey, M.; Talamas, E.; Tucker, E.; Vilhelmsen, L.; Ward, P. \& Wharton, R. 2012. A hymenopterists' guide to the Hymenoptera Anatomy Ontology: utility, clarification, and future directions. Journal of Hymenoptera Research, 27:67-88. D0I

Shcherbakov, D.E. 1980. Morphology of the pterothoracic pleura of Hymenoptera. 1. Groundplan. Zoologicheskii Zhurnal, 59(11): 1644-1653.

Shcherbakov, D.E. 1981. Morphology the pterothoracic pleura in Hymenoptera. 2. Modifications of the groundplan. Zoologicheskii Zhurnal, 60(2): 205-213.

Snodgrass, R.E. 1909. The thorax of insects and the articulation of the wings. Proceedings of the United States National Museum, 36(1687): 511-595.

Snodgrass, R.E. 1910. The thorax of the Hymenoptera. Proceedings of the United States National Museum, 39: 37-21. D0I

Snodgrass, R.E. 1935. Principles of insect morphology. New York, McGraw-Hill. DOI 
Snodgrass, R.E. 1942. The skeleto-muscular mechanisms of the honeybee. Smithsonian Miscellaneous Collections, 103: 1-120.

Sorg, M. 1988. Zur Phylogenie und Systematik der Bethylidae (Insecta, Hymenoptera, (hrysidoidea). Sonderveröffentlichungen des Geologisches Institut der Universität Köln, 63: 1-146.

Stein, P.R.W. \& Azevedo, C.0. 2007. Synopsis of lobatifrons species-group (Hymenoptera: Bethylidae, Rhabdepyris) from Neotropical region, with redefinition of the group. Zootaxa, 1444: 23-34.

Stein, P.R.W.; Alencar I.D.C.C.; Barbosa, D.N. \& Azevedo, C.0. 2011. Revision of Epyris afer (Magretti, 1884), comb. rev. (Hymenoptera: Bethylidae) with new synonymy and description of two new species. Zootaxa, 3032: 17-32.

Terayama, M. 2006. Insects of Japan, Bethylidae (Hymenoptera). Vol. 1. Fukuoka, Touka Shobo Co.

Terayama, M. 2008. Two new species of Epyris (Insecta, Hymenoptera, Bethylidae) from Sulawesi island of Indonesia. Japanese Journal of Systematic Entomology, 14: 145-149.

Vargas, J.M. \& Azevedo, C.0. 2008. Revision of Alongatepyris (Hymenoptera: Bethylidae) with descripition of a new species from Colombia. Revista Brasileira de Zoologia, 25(4): 843-846.

Vargas, J.M. \& Azevedo, C.0. 2016a. Three new species of Pararhabdepyris Gorbatovsky (Hymenoptera, Bethylidae) from Central Africa and the Arabian Peninsula. Zootaxa, 4117: 429-439. DOI

Vargas, J.M. \& Azevedo, C.0.2016b. Discovery of the male of Galodoxa torquata Nagy (Hymenoptera, Bethylidae), with emended generic diagnosis. In: Robillard, T.; Legendre, F.; Villemant, C. \& Leponce, M. (Eds.). Insects of Mount Wilhelm, Papua New Guinea. Paris, Muséum National d'Histoire Naturelle. p. 451-564.
Vilhelmsen, L.; Mikó, I. \& Krogmann, L. 2010. Beyond the wasp-waist: structural diversity and phylogenetic significance of the mesosoma in apocritan wasps (Insecta: Hymenoptera). Zoological Journal of the Linnean Society, 59: 22-194. D0I

Waichert, C.\& Azevedo, C.0. 2004. Fourteen new Species of Pseudisobrachium (Hymenoptera, Bethylidae) from Atlantic Rain Forest of Espírito Santo, Brazil. Zootaxa, 661: 1-22.

Waichert, C. \& Azevedo, C.0. 2009. Phylogenetic analysis of Rhabdepyris (Hymenoptera: Bethylidae) and redefinition of generic limits based on morphological characters. Zootaxa, 2284: 1-29.

Waichert, C. \& Azevedo, C.0. 2012. The genus Prorops Waterson, 1923 (Hymenoptera, Bethylidae) from Madagascar. European Journal of Taxonomy, 16: 1-11.

Wharton, R.A. 2006. The species of Sternaulopius Fischer (Hymenoptera: Braconidae, Opiinae) and the braconid sternaulus. Journal of Hymenoptera Research, 15: 317-347.

Willsch, M.; Friedrich, F.; Baum, D.; Jurisch, I. \& Ohl, M. 2020. A comparative description of the mesosomal musculature in Sphecidae and Ampulicidae (Hymenoptera, Apoidea) using 3D techniques. Deutsche Entomologische Zeitschrift, 67:51-67. D01

Yoder, M.; Mikó, I.; Seltmann, K.; Bertone, M. \& Deans, A. 2010. A gross anatomy ontology for Hymenoptera. PLOS ONE, 5(12). DOI

Zamprogno, L.N. \& Azevedo, C.0. 2014. Phylogeny and reclassification of Pristocera Klug (Hymenoptera: Bethylidae). Insect Systematics \& Evolution, 45: 1-49. DOI 